\title{
Sea ice thickness in the Eastern Canadian Arctic: Hudson Bay Complex \& Baffin Bay
}

\author{
Jack C. Landy ${ }^{\mathrm{a}, \mathrm{b}, * 1}$, Jens K. Ehn ${ }^{\mathrm{a}}$, David G. Babb ${ }^{\mathrm{a}}$, Nathalie Thériault ${ }^{\mathrm{a}}$, David G. Barber ${ }^{\mathrm{a}}$ \\ a Centre for Earth Observation Science, Riddell Faculty of Environment Earth and Resources, University of Manitoba, Winnipeg, Canada \\ b Bristol Glaciology Centre, School of Geographical Sciences, Faculty of Sciences, University of Bristol, Bristol, United Kingdom
}

\section{A R T I C L E I N F O}

\section{Keywords:}

Sea ice thickness

Eastern Canadian Arctic

ICESat

Cryosat-2

Sea ice deformation

Ocean freshwater budget

\begin{abstract}
A B S T R A C T
Past observations of sea ice thickness in the Eastern Canadian Arctic (ECA) have generally been restricted to drill-hole measurements at a few local sites on landfast ice. Here we use data from the laser altimeter ICESat and the radar altimeter Cryosat-2 to present a 14-year record (2003-2016) of high-resolution and spatially extensive ice thickness observations for the ECA and identify 12 sub-regions with distinct patterns. The mean sea ice growth rate within the seasonally ice-covered ECA from November to April is $23 \mathrm{~cm} \mathrm{mo}^{-1}\left(565 \mathrm{~km}^{3} \mathrm{mo}^{-1}\right)$, with the fastest increase in thickness occurring through strong ice convergence and deformation in eastern Hudson Bay and Foxe Basin. Our results demonstrate characteristically asymmetrical distributions of sea ice thickness in both Hudson Bay and Baffin Bay, but in opposing directions. In Hudson Bay the spring ice cover is $40 \mathrm{~cm}$ thicker in the eastern region compared to the northwestern region, whereas in Baffin Bay the ice is $20 \mathrm{~cm}$ thicker in the western half of the bay compared to the eastern half. In Hudson Bay we find that years with strong and positive ice drift vorticity (i.e. cyclonic and convergent conditions) correlate with increasingly asymmetrical sea ice covers, with the level of west-east asymmetry varying from 2 to $11 \mathrm{~cm}$ per $100 \mathrm{~km}$. However, in Baffin Bay the ice drift vorticity is typically negative (i.e. anticyclonic and divergent) with no obvious link to the asymmetry of the spring ice cover. Finally, we estimate that large interannual variations in spring sea ice volume within the ECA lead to $\pm 15 \%$ variations in the volume of freshwater available at the ocean surface during summer.
\end{abstract}

\section{Introduction}

Not only has the summertime area of Arctic sea ice declined over the past few decades (Comiso, 2012), but recent studies have demonstrated that the thickness of the ice cover has also been significantly reduced since the turn of the century (Kwok and Rothrock, 2009), (Kwok et al., 2009), (Laxon et al., 2013), (Kwok and Cunningham, 2015). Regular and spatially extensive sea ice thickness observations are important for a number of reasons, including: estimating the volume of the Arctic sea ice cover (Kwok and Cunningham, 2015); validating numerical sea ice models (Schweiger et al., 2011); estimating the freshwater flux entering the ocean following summer melt and downstream effects of this flux on oceans at lower latitudes (Granskog et al., 2011; Morison et al., 2012); evaluating marine mammal habitat, for instance polar bear migration routes (Regehr et al., 2007); and forecasting marine transportation (shipping or cruise) routes (Stewart et al., 2010); among many others. Recent advances in satellite altimetry are overcoming the considerable challenges involved with obtaining regional sea ice thickness estimates.
Most studies have focused on the central Arctic sea ice pack, while there have been few published observations of sea ice thickness at lower latitudes, for example in the Eastern Canadian Arctic (ECA), which is a region of significant importance for the global freshwater cycle. In this study, we use satellite altimeter measurements of sea ice freeboard to provide the first long-term (decadal) estimates for sea ice thickness and volume over the entire ECA.

The ECA consists of several seasonally ice-covered water bodies, including the two largest: Hudson Bay and Baffin Bay. Hudson Bay is a large inland subarctic sea that is isolated from open ocean circulation and therefore acts as a relatively independent system from the Atlantic and Arctic Oceans (Stewart and Barber, 2010). The larger area of the Hudson Bay Complex (HBC) refers to Sub-Regions SR1-7 (Fig. 1) defined in this study. Currents in the HBC are primarily wind-driven and cyclonic, affected only by cold-water intrusions through relatively small openings in the north via Fury and Hecla Straits and northeast via Hudson Strait (Hochheim and Barber, 2010). In contrast, Baffin Bay (SR10-11) is continuously affected by Arctic Ocean water flowing into

\footnotetext{
* Corresponding author at: Centre for Earth Observation Science, University of Manitoba, 125 Dysart Road, Winnipeg, Manitoba R3T 2N2, Canada

E-mail address: jack.landy@bristol.ac.uk (J.C. Landy).

${ }^{1}$ Now at: Bristol Glaciology Centre, 12 Berkeley Square, Bristol, Somerset, United Kingdom, BS8 1SS.
} 


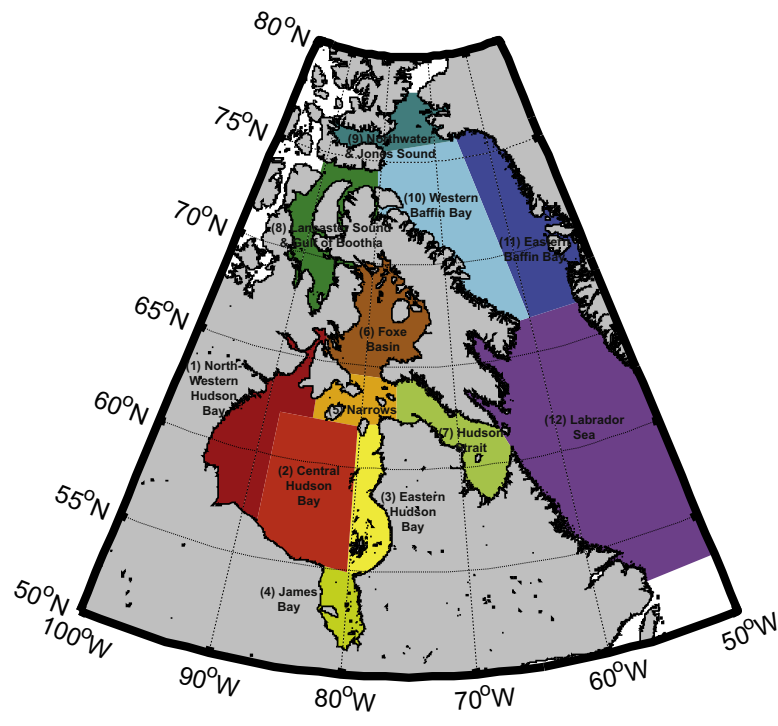

Fig. 1. Twelve sub-regions of the Eastern Canadian Arctic.

the bay through Nares Strait and Lancaster Sound, as well as cycling with Atlantic water across Davis Strait through the Baffin Island \& West Greenland Currents. Mean circulation in Baffin Bay is cyclonic, with stronger currents in summer and fall than in winter and spring, but a southward counter-current on the Greenland Shelf contributes to strong horizontal shears in the eastern region of the bay (Tang et al., 2004).

The sea ice cover within the ECA generally undergoes one full freeze-thaw cycle each year. There is typically no multi-year ice in the HBC, whereas Baffin Bay retains a small portion while some multi-year ice is imported into the bay from the central Arctic Ocean through Nares Strait (SR9) (Kwok, 2005). Across the ECA ice formation progresses from the northwest to the southeast (Stern and HeideJørgensen, 2003) (Gagnon and Gough, 2005) with a two-month delay between freeze-up in Foxe Basin (SR6) and the Labrador Sea (SR12). Studies have linked significant declining trends in ECA sea ice concentration (from $5 \%$ to $9 \%$ decade $^{-1}$ (Parkinson and Cavalieri, 2008)), to increasing surface air temperatures (SATs), particularly in the spring and fall (Tang et al., 2004) (Hochheim and Barber, 2010) (Hochheim et al., 2011) Hochheim and Barber, 2014. These results are supported by observations of later fall freeze-up in the northern region of Hudson Bay and in Baffin Bay, but earlier melt onset in James Bay (SR4) and the Labrador Sea in recent decades (Gagnon and Gough, 2005) (Stroeve et al., 2014).

The few observational studies of sea ice thickness in the Hudson Bay Complex have been restricted to in situ drill-hole measurements at seven sites on landfast first-year ice around the coast prior to 2003. Average winter maximum ice thickness has been estimated from these sites as approximately 0.9 to $2.4 \mathrm{~m}$ (Gagnon and Gough, 2006). From the same dataset (Gough et al., 2004) identified east-west asymmetry in the long-term trends in ice thickness between approximately 1960 and 2000 , with ice thickening $\left(+0.1-1.5 \mathrm{~cm} \mathrm{yr}^{-1}\right)$ on the western side of Hudson Bay (SR1), but thinning $\left(-0.5-0.8 \mathrm{~cm} \mathrm{yr}^{-1}\right)$ on the eastern side (SR3) (Gagnon and Gough, 2006). Numerical modelling studies of sea ice in the HBC provide simulated estimates for the average winter maximum ice thickness ranging from around 1 to $>2.5 \mathrm{~m}$, although these studies disagree on the spatial distribution of sea ice (Wang et al., 1994), (Saucier et al., 2004), (Joly et al., 2011). Ice thicknesses in Baffin Bay and the Labrador Sea are highly variable. For instance, (Valeur et al., 1996) combined restricted ice thickness measurements with a thermodynamic sea ice model to demonstrate that annual maximum ice thickness decreases from $1.75 \mathrm{~m}$ at the coast of Baffin Island in the northwest to $<0.75 \mathrm{~m}$ in the southeast. Freshwater budgets have indicated that $20-90 \%$ more ice is produced in the ECA than estimated by concurrent in situ ice thickness data (Prinsenberg, 1988) (Prinsenberg and Peterson 2003), because these data fail to account for the contribution of pressure ridges in the upper tail of the ice thickness distribution. In summary, observations of sea ice thickness in the ECA are extremely sparse and typically more than a decade out-of-date, and model predictions are not validated with sufficient observations nor agree on the regional distribution of the ice cover.

The thickness distributions within the ECA are significantly affected by the presence of coastal polynyas. In particular, a large polynya has been observed to form occasionally throughout the winter and spring in the northwestern region of Hudson Bay (SR1) e.g. (Gough et al., 2004); often triggered by the smaller Roes Welcome Sound Polynya (Barber and Massom, 2007). A second large, persistent polynya forms in the North Water, at the northern end of Baffin Bay and Jones Sound (SR9), during most years in spring (Tang et al., 2004). Both of these features are thought to principally be latent-heat polynyas. The NW Hudson Bay Polynya is caused by strong offshore westerly winds opening up areas of water along the northwestern coast and enhancing ice production (Saucier et al., 2004). The North Water Polynya is caused by an ice arch which forms in Kane Basin and limits the influx of ice from the Arctic Ocean, in conjunction with a heat flux from upwelling of the West Greenland Current (Melling et al., 2001). The ice covers within both of these polynyas are generally thin, intermittent or absent. Sea ice that grows thermodynamically is continuously exported by winds to the south and east in Hudson Bay and to the south in Baffin Bay.

With the arrival of NASA's ICESat mission, operational from 2003 to 2008, and ESA's Cryosat-2 mission, from 2010 until present, satellite altimetry has become the preeminent technique for acquiring high temporal and spatial resolution remote estimates of Arctic sea ice thickness. Total snow plus sea ice freeboard can be obtained from ICESat by calculating the height difference between laser echoes from the sea surface (e.g. from leads between ice floes) and echoes from the snow surface. On the other hand, only sea ice freeboard is obtained from Cryosat-2 because the radar wave theoretically penetrates the snowpack. Snow depth, snow density and sea ice density must be estimated or parameterized to convert ice freeboard to thickness, following Archimedes' principle, e.g. (Kwok and Rothrock, 2009), (Laxon et al., 2013). Ice thickness can generally be retrieved with an uncertainty $<0.5 \mathrm{~m}$ (Ricker et al., 2014). By applying this technique, past studies have been able to document the long-term decline in sea ice volume within the Arctic Ocean during the 2000s (Kwok and Rothrock, 2009). Interannual variations in Arctic ice volume have also been detected, including for instance the severe loss in 2007 (Maslanik et al., 2007) and minor rebound in 2013 and 2014 (Tilling et al., 2015). However, past studies have commonly truncated their observations above a latitude of $70^{\circ}$, because the satellite orbital coverage is sparser and the existing snow climatology is invalid at lower latitudes. Instead they have focused only on the central Arctic Ocean and neglected lower latitude Arctic seas such as Hudson Bay and Baffin Bay.

Here we utilize altimeter observations of sea ice freeboard from ICESat and Cryosat-2, complimented with thin-ice thickness observations from the SMOS L-band radiometer, to derive a near-continuous 14-year record of sea ice thickness in the entire Eastern Canadian Arctic, from 2003 to 2016. In Section 2 we outline the procedures used to process raw laser/radar echoes and obtain sea ice freeboard, as well as our methods to estimate snow depth and parameterize snow and sea ice densities. We introduce an error budget that can be used to analyze the uncertainty of the retrieved ice thickness estimates. In Section 3 we analyze decadal trends and interannual variability in sea ice thickness and volume within several regions of the ECA (Fig. 1). In Section 4 we evaluate whether observed interannual variability in Hudson Bay and Baffin Bay ice thickness distributions can be explained by patterns of ice motion, and discuss the implications of our results for the freshwater budget of the ECA. Finally, in Section 5 we conclude our findings and outline potential avenues for future research. 


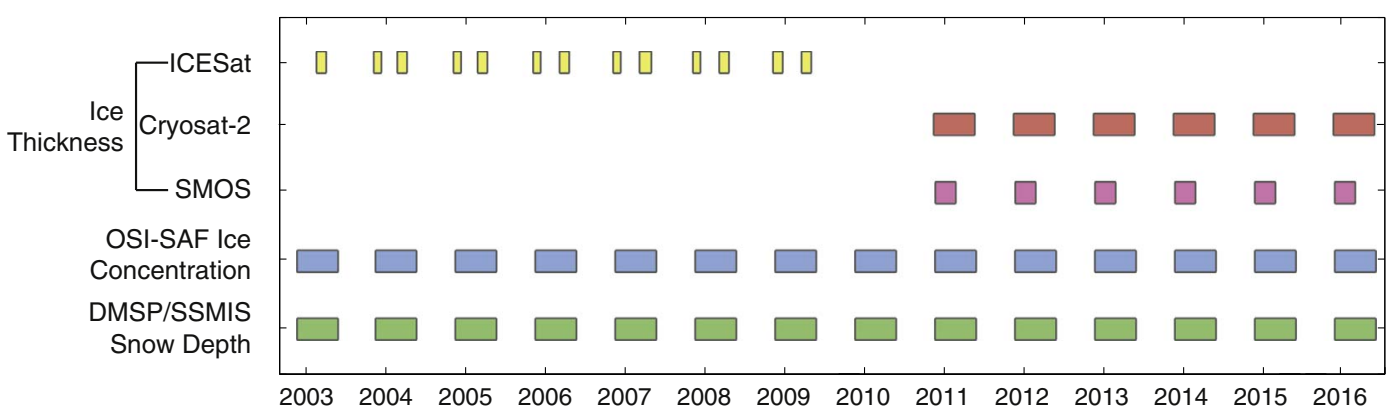

Fig. 2. Temporal coverage of the different satellite datasets used in this study.

\section{Data and methods}

Various methods for estimating sea ice thickness from satellite observations have been outlined in previous studies, for ICESat (Forsberg and Skourup, 2005), (Kwok et al., 2007), (Kwok and Cunningham, 2008), (Farrell et al., 2009), (Kwok and Rothrock, 2009); Cryosat-2 (Laxon et al., 2013), (Kurtz et al., 2014), (Ricker et al., 2014), (Kwok and Cunningham, 2015), (Tilling et al., 2015); and SMOS (Kaleschke et al., 2012), (Tian-Kunze et al., 2014). In this study we do not present substantial new methods; rather we integrate and apply a selection of these published techniques with minor alterations to an area not considered within previous studies. The temporal coverage of the satellite data used in the study is illustrated in Fig. 2. It is worth noting that while implementing our method we ensured that the processing algorithms for ICESat and Cryosat-2 data were as close as possible, to prevent inconsistencies or biases emerging between the two datasets. However, the algorithms were not identical due to differences between the sensors, including footprint diameter, sampling interval, laser versus radar altimeter, etc. Detailed descriptions of our methods for retrieving sea ice freeboard, sea ice thickness and snow depth are provided in the supplementary materials.

\subsection{Satellite altimeter observations of sea ice freeboard}

The ICESat Geoscience and Laser Altimeter System (GLAS) was a profiling laser altimeter (wavelength $1064 \mathrm{~nm}$ ) which measured sea ice or snow-covered sea ice elevation above a reference Earth ellipsoid, with footprints $\sim 70 \mathrm{~m}$ in diameter spaced at $\sim 170 \mathrm{~m}$ intervals, up to a latitudinal limit of $86^{\circ}$ (Kwok et al., 2006). The latest version of the ICESat GLAS data available at the time of analysis was Version 34 of the Level 2 GLA05 \& GLA13 products, available from the National Snow and Ice Data Center (NSIDC) at http://nsidc.org/data/icesat/ (Zwally et al., 2014) from November to March, for the years 2003-2008. Surface elevation (relative to the TOPEX/Poseidon ellipsoid) is determined by subtracting the range of a GLAS pulse from the height of the satellite above the earth, and is provided in the GLA13 product following inhouse waveform processing at NSIDC. For our study, valid elevation samples were obtained by filtering and correcting the raw data for known geodetic and oceanographic biases, including geoid undulations, tides, dynamic topography of the ocean and the inverted barometer effects (see Supplementary Material 1). Sea ice and sea surface (lead) elevation samples were separated using an adapted version of the approach of (Kwok et al., 2007) and (Kwok and Cunningham, 2008), based on differences in the reflective properties and relative elevation of these surface types. Sea ice freeboard was calculated from the height difference between the ice surface elevation and sea level.

Cryosat-2 (CS-2) is a profiling radar altimeter (Ku-band) that theoretically penetrates snow if it is present on sea ice, and measures the sea ice elevation above a reference ellipsoid. The footprint of CS-2 is pulseDoppler-limited $\sim 300 \mathrm{~m}$ along the track and pulse-limited $\sim 1500 \mathrm{~m}$ across the track of the beam, with samples spaced at $\sim 300 \mathrm{~m}$ intervals, up to a latitudinal limit of $88^{\circ}$ (Wingham et al., 2006). The latest version of the CS-2 data available at the time of analysis was Baseline C of the Level 1B and Level 2, SAR and (interferometric) SARIn data, accessed from the European Space Agency (ESA). Data were available for November-April for each year between 2010 and 2016. Although data were also available for May, the snow cover within the ECA generally begins to start melting during May which causes the principal radar scattering surface (i.e. the altimeter's retracker range) to migrate up from the snow-ice interface into the snowpack (Kwok, 2014), biasing the ice thickness estimates. The assumption of full radar penetration into the snowpack is discussed further in Supplementary Material 2. Surface elevation can be determined by subtracting the range of a CS-2 pulse from the height of the satellite above the earth. To obtain the range, we applied a 'retracking' correction to each empirical CS-2 waveform, based on fitting a theoretical waveform function to the echo and then simple thresholding, following (Giles et al., 2007), (Laxon et al., 2013) and (Kwok and Cunningham, 2015) (see Supplementary Material 2). We used only the power information in our analysis of SARIn echoes and truncated the waveforms from 512 to 128 bins before processing (Kurtz et al., 2014). In this study we assumed that a threshold of $70 \%$ of the echo power represented the mean scattering surface of the retracked fitted waveform for both sea ice and leads, based on analysis of (Laxon et al., 2013), (Kurtz et al., 2014) and (Ricker et al., 2014). Valid elevation samples were obtained by filtering and correcting the raw data for known geodetic and oceanographic biases. To ensure we maintained a consistent approach between ICESat and CS-2 processing methods, sea ice and sea surface (lead) radar waveforms were classified according to both their elevation and shape (backscattering) properties, using an adapted version of the approach of (Laxon et al., 2013; Kurtz et al., 2014; Ricker et al., 2014). Considerable detail on the design of the processing algorithms and techniques used to filter out waveforms from mixed surface ice/lead/open water/land types is provided in Supplementary Material 2. For instance, our filtering step included a series of dedicated algorithms to separate and classify pure waveforms from sea ice and leads. Sea ice freeboard was calculated from the height difference between the ice surface elevation and sea level. For verification purposes, we provide the raw winter (March) estimates for sea ice freeboard and distance of samples to their closest lead, separated for each satellite mission and between major regions of the ECA, in Table 1.

\subsection{Snow data}

To estimate sea ice thickness from freeboard, it is necessary to measure or parameterize the depth and density of snow existing on the ice cover, as well as the densities of ice and seawater. Past studies have generally used the 'Warren climatology', which is based on in situ snow measurements from Russian drifting stations in the central Arctic Ocean (Warren et al., 1999). Since this climatology did not cover our study area, we chose to reapply the technique of (Markus and Cavalieri, 1998) to obtain snow depth from DMSP/SSM/I-SSMIS brightness temperatures (25-km, available from NSIDC at http://nsidc.org/data/NSIDC0001\#) (Maslanik and Stroeve, 2016), which were available for 2003- 
Table 1

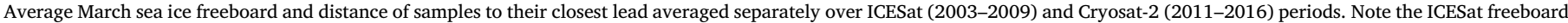
is the total snow plus ice freeboard $h_{f_{\text {total }}}$ and the Cryosat-2 freeboard is only the ice freeboard without the snow wave-speed correction applied $h_{f_{i}}$

\begin{tabular}{|c|c|c|c|c|}
\hline & \multicolumn{2}{|c|}{ Sea ice freeboard $[\mathrm{m}]$} & \multicolumn{2}{|c|}{ Distance to closest lead [km] } \\
\hline & ICESat & Cryosat-2 & ICESat & Cryosat-2 \\
\hline Hudson bay complex (SR1-7) & $0.231 \pm 0.146$ & $0.123 \pm 0.121$ & $23 \pm 36$ & $34 \pm 43$ \\
\hline Baffin bay \& Labrador sea (SR9-12) & $0.233 \pm 0.156$ & $0.106 \pm 0.103$ & $16 \pm 30$ & $42 \pm 47$ \\
\hline
\end{tabular}

(a)

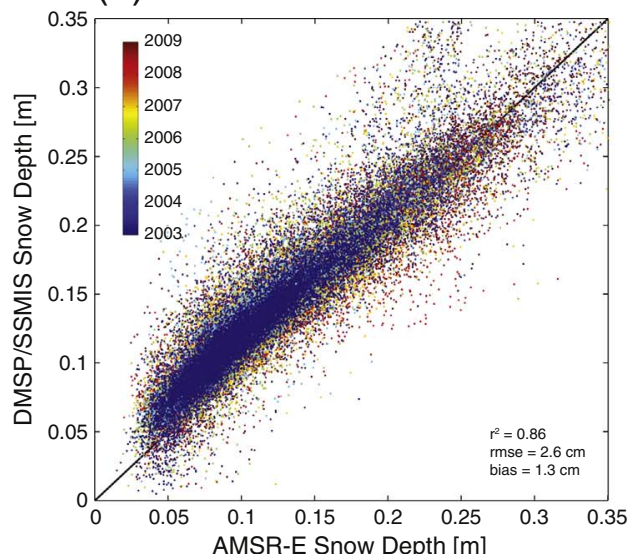

(b) AMSR-E minus DMSP/SSMIS

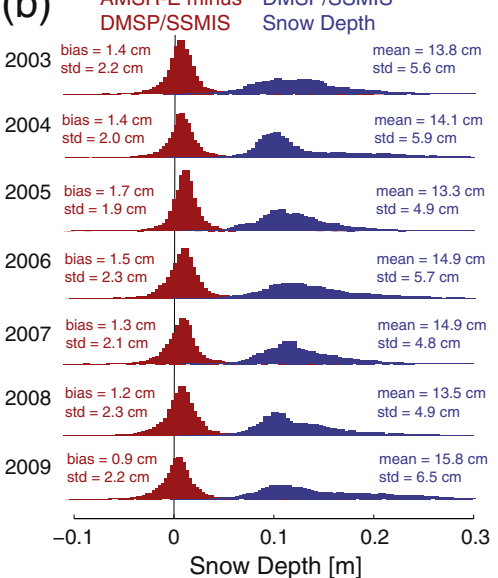

Fig. 3. (a) Comparison between snow depth estimated from DMSP/SSMIS brightness temperatures (used in this study) and estimated from AMSR-E brightness temperatures (provided by NSIDC), over the concurrent period 2003-2009. (b) Histograms of annual mean snow depth from DMSP/SSMIS (blue) and difference between AMSR-E and DMSP/SSMIS snow depths (red) for 2003-2009. (c) 'Climatological' mean snow depth in spring (March-April), from DMSP/SSMIS brightness temperatures, for 2003-2016. The bold line gives the mean ice edge (20\% ice concentration). (For interpretation of the references to colour in this figure legend, the reader is referred to the web version of this article.)

\section{(c)}

Spring (Mar-Apr) Mean

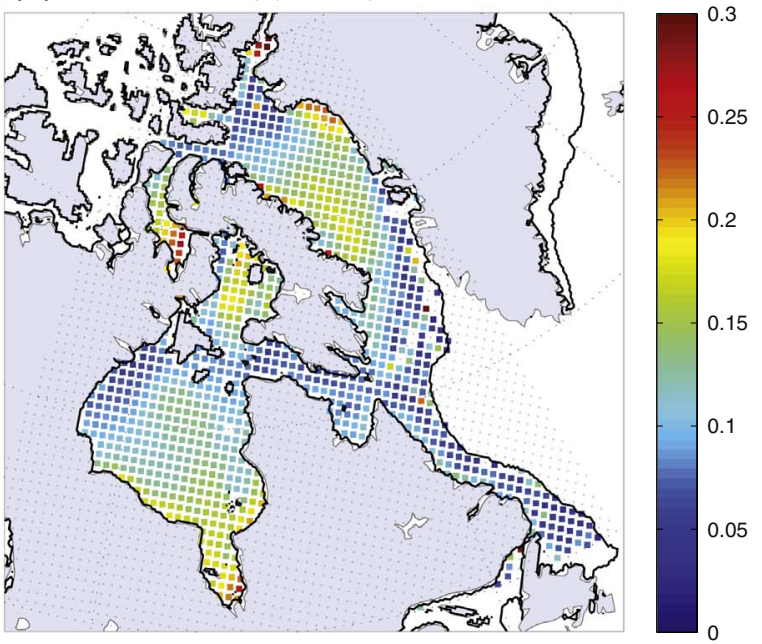

now Depth $[\mathrm{m}]$

present (see Supplementary Materials 3). The coefficient of determination and RMSE between our 5-day averaged snow depth estimates and those from resampled 25-km AMSR-E data, for December-May over the concurrent period of observations 2003-2009, were 0.86 and $2.6 \mathrm{~cm}$, respectively (Fig. 3a). Fig. 3b demonstrates that there are no anomalous biases between the datasets for individual years and that the snow depth distribution was similar between years. Mean 2003-2016 spring snow depth is presented for our study region in Fig. 3c.

For snow density, we used a modified version (Kwok and Cunningham, 2008) of the seasonally-varied density observations provided in (Warren et al., 1999), but applied the same spatially-constant density for all freeboard observations on a given day of year.

\subsection{Sea ice thickness \& error budget}

Sea ice thickness $h_{i}$ was estimated from ICESat freeboard observations using: $h_{i}=\left(\frac{\rho_{w}}{\rho_{w}-\rho_{i}}\right) h_{f_{\text {total }}}-\left(\frac{\rho_{w}-\rho_{s}}{\rho_{w}-\rho_{i}}\right) h_{s}$,

where $h_{f_{\text {total }}}$ is the total ice plus snow freeboard, $h_{s}$ is the snow depth, and bulk densities for sea ice $\rho_{i}$, snow $\rho_{s}$ and seawater $\rho_{w}$ provide the scaling for hydrostatic equilibrium. In contrast, sea ice thickness was estimated from CS-2 freeboard observations using:

$h_{i}=\left(\frac{\rho_{w}}{\rho_{w}-\rho_{i}}\right) h_{f_{i}}+\left(\frac{\rho_{s}}{\rho_{w}-\rho_{i}}\right) h_{s}$,

where $h_{f_{i}}$ is the ice-only freeboard, because the radar was assumed to penetrate the snow pack. A height correction $h_{c}$ was applied to the radar observations as follows: $h_{f_{i}}=h_{f_{\text {radar }}}+h_{c}$, before evaluating Eq. (2), to account for the lower wave propagation speed within the snowpack (Kwok and Cunningham, 2015). The correction is given by:

$h_{c}=h_{s}\left(1-\frac{c_{s}}{c}\right)$, 
where $c_{s}$ is the speed of light in snow, parameterized by $c_{s}=c$ $\left(1+0.51 \rho_{s}\right)^{-1.5}$ (Ulaby et al., 1982). Snow density was obtained from W99 as described above, seawater density was taken as $1024 \mathrm{~kg} \mathrm{~m}^{-3}$, and sea ice density was obtained from an ice thickness-dependent parameterization: $\rho_{i}\left(h_{i}\right)=936-18 h_{i}^{0.5} \mathrm{~kg} \mathrm{~m}^{-3}$, following (Kovacs, 1996).

We attempted to approximate the random uncertainty $\sigma$ of each ice thickness estimate by accounting for individual uncertainties in: snow depth, snow density, sea ice density, seawater density, sea-surface height (SSH) with respect to the geoid, radar speckle noise, and possible volume scattering of the CS-2 radar wave within the snowpack rather than from the snow-ice interface. Individual uncertainty components are listed in Table S1 in Supplementary Materials 4 along with the references used, where applicable. All components have fixed uncertainty, with the exceptions of the SSH and, in the case of CS-2 measurements, the speckle noise and radar propagation uncertainty. Random uncertainties were assumed to be uncorrelated and could therefore be combined, using Gaussian propagation of uncertainty, to generate a single uncertainty estimate for each ICESat or CS-2 observation (Kwok and Cunningham, 2008), (Ricker et al., 2014). However, for the majority of our analyses we gridded the ice thickness measurements at a resolution of $50 \mathrm{~km}$, using a mean filter inverselinearly weighted by the sample uncertainty and distance (Geiger et al., 2015). Thus gridded mean thickness uncertainty $\bar{\sigma}$ decreased proportional to $\sqrt{N}$, where $N$ is the number of samples. Samples with zero thickness (i.e. open water), were removed prior to gridding. Minimum $N$ was set at 10 samples, although the mean value of $N$ for the ICESat data was 191 and for the CS-2 data was 241 .

\subsection{Thin-ice thickness from SMOS}

Both the relative systematic and random uncertainties of altimeterbased ice thickness observations are known to be higher in thinner ice e.g. (Ricker et al., 2014). For instance, the speckle noise in individual Cryosat-2 samples places a lower limit on the reliably detectable ice thickness of approximately $0.5 \mathrm{~m}$ (Kurtz et al., 2014). Between November and January, the thickness of ice in the HBC can often be below this limit (Gagnon and Gough, 2006). We therefore obtained estimates of the thickness of thin sea ice from the Soil Moisture and Ocean Salinity (SMOS) satellite (Kaleschke et al., 2012) to integrate with the altimeter measurements. However, since SMOS data are only available for the CS-2 period: 2010-2016, we chose to only integrate these data between November and January, thereby improving our estimates for ice thickness and volume in the fall and early winter months. Although this prohibited us from analyzing ice thickness trends between ICESat and CS-2 data in November, we could still analyze trends in March. We chose not to integrate the SMOS data between February and April, because the average ice thickness in these months is typically much $>0.5 \mathrm{~m}$.

Daily Level 3C SMOS thin ice thickness grids, with a resolution of $12.5 \mathrm{~km}$, were obtained from the Integrated Climate Data Center at the University of Hamburg (available at: http://icdc.zmaw.de/1/daten/ cryosphere/13c-smos-sit.html) (Tian-Kunze et al., 2013, updated 2016). We calculated monthly average ice thickness from these daily estimates, for November through January 2010-2015, using only data where both the thickness and uncertainty was $\leq 1 \mathrm{~m}$. However, the SMOS observations systematically underestimate the true ice thickness, potentially by 10 s of centimeters, because (1) ice with a true mean thickness $>1 \mathrm{~m}$ cannot be retrieved and (2) the algorithm does not account for ice concentration $<100 \%$ (Tian-Kunze et al., 2014). Consequently, we calculated monthly ice thickness as an average of SMOS and CS-2 observations in areas where the SMOS ice thickness was $\leq 1 \mathrm{~m}$ (Fig. 4a), but in the remaining ice-covered area used only CS-2 observations. Fig. 4a illustrates that the area of utilized SMOS data was largest in December, whereas in January the ice in regions such as Southeastern Hudson Bay began to thicken above $1 \mathrm{~m}$ and the SMOS data were omitted. The distributions of sea ice thickness from SMOS and CS-2 in the zone around the transition in validity between datasets (approximately $1 \mathrm{~m}$ ) are very similar (Fig. 4b). Both distributions show decreasing observations as the ice thickness increases from 0.9 up to $1.3 \mathrm{~m}$, although there are less CS-2 than SMOS observations for ice thickness $<0.9 \mathrm{~m}$ because ice with a thickness approaching $0.5 \mathrm{~m}$ is less easily detected by CS- 2 .

\subsection{Sea ice volume}

A lack of spatially ubiquitous and consistent year-to-year ice thickness observations within each sub-region of the HBC presented a challenge for estimating changes in the volume of sea ice. Without accounting for missing data, ice volume estimates obtained from an integral of ice thickness and concentration grids would be underestimated. To overcome this issue, we first interpolated the ice thickness grids using nearest-neighbour interpolation to fill small gaps; however, this technique could not reliably be used to fill gaps larger than $100 \mathrm{~km}$. Thus, to calculate sea ice volume from the ice thickness observations within a sub-region we evaluated the following:

$V_{i}=\Delta x^{2}\left[\sum_{j=1}^{N_{\text {usable }}}\left(h_{i} C_{i}\right)_{j}+\overline{h_{i}} \sum_{j=1}^{N_{\text {missing }}}\left(C_{i}\right)_{j}\right]$,

where $\Delta x$ is the grid cell size ( $50 \mathrm{~km}$ ), $N_{\text {usable }}$ and $N_{\text {missing }}$ are the number of usable and missing ice thickness grid cells, respectively, $h_{i}$ is the ice thickness and $C_{i}$ is the ice concentration within grid cell $j$, and $\overline{h_{i}}$ is the mean ice thickness within the region. Ice volume uncertainty was estimated by integrating the uncertainties in ICESat/CS-2 and SMOS data for the months November through January. Additional uncertainty involved with estimating the missing areas was then calculated as the standard deviation of $h_{i}$, for all months, weighted by the number of missing to usable grid cells. The mean fraction of usable ice thickness data: $N_{\text {usable }} /\left(N_{\text {usable }}+N_{\text {missing }}\right)$, for all months studied, was $78 \%$. The minimum fraction of usable data was $26 \%$, with an equivalent uncertainty of $\pm 175 \mathrm{~km}^{3}$ (16\%), which occurred in November 2004 when sea ice concentration was low within the ECA. The maximum fraction of usable data was $97 \%$, with an equivalent uncertainty of \pm $68 \mathrm{~km}^{3}$ (2\%), which occurred in March 2006.

\subsection{Auxiliary data}

Sea ice concentration was obtained from the daily $12.5-\mathrm{km}$ OSI-SAF global ice concentration reprocessing dataset, available at http://osisaf. met.no/p/ice/) (EUMETSAT, 2015). Ice concentration data were used to define the valid geographical area of altimeter observations, as described above.

Kinematic parameters of the Hudson Bay and Baffin Bay sea ice motion fields were derived from weekly 25-km Polar Pathfinder sea ice motion vectors (Version 3, available from NSIDC at: http://nsidc.org/ data/NSIDC-0116) (Tschudi et al., 2016). Unambiguous drift vectors were only available in areas $>25 \mathrm{~km}$ from the coastline. Mean ice drift speed and direction were obtained for select time periods from the product of vertical $u$ and horizontal $v$ component vectors. We also calculated the velocity component in the west-east direction across Hudson Bay, i.e. from northwestern (sub-region, SR1) to eastern (SR5) Hudson Bay (Fig. 1), to examine whether ice drift affects spatial variations in the Hudson Bay ice thickness distribution. By tracking the ice drift vectors across the boundaries between sub-regions 1, 2 and 5, we could estimate the mean speed of ice moving into or out of each region. Finally, the kinematic parameters: ice divergence, vorticity and shear, were calculated following (Kwok, 2001) (details in Table 4), which characterize deformation within the ice pack. 
(a) Regions where SMOS Data are used

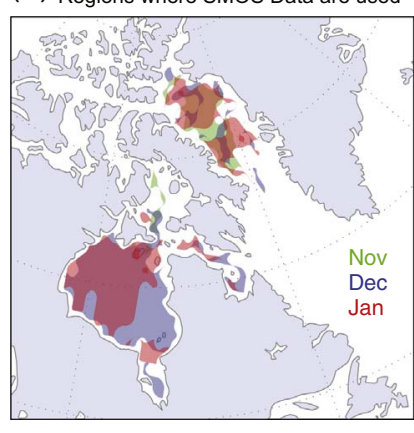

(b)

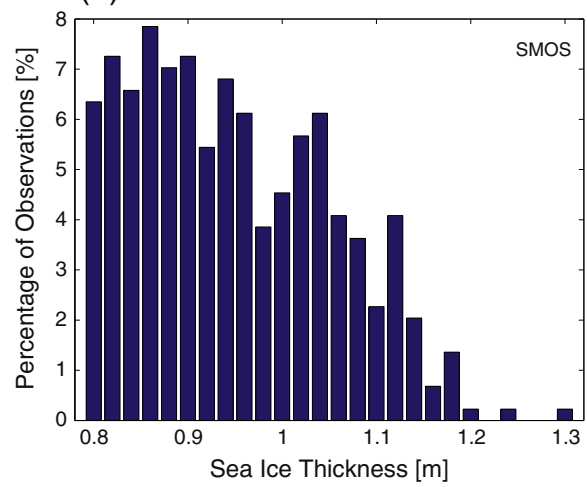

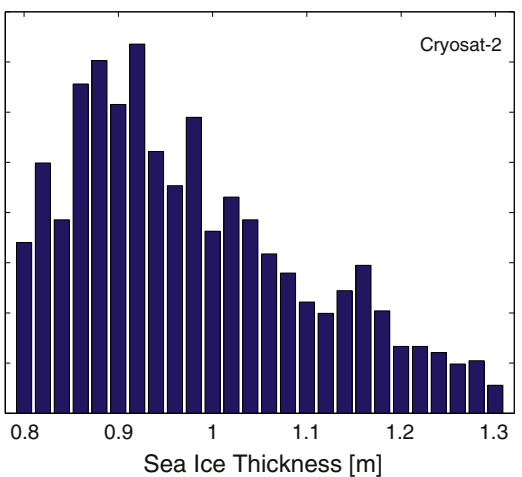

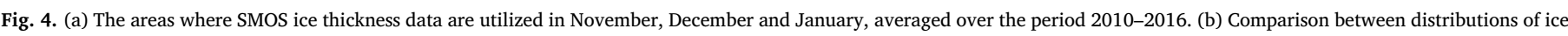
thickness from SMOS and Cryosat-2 within the transition zone in validity $(0.8-1.3 \mathrm{~m})$ between the two datasets.

\section{Results}

\subsection{Regional distribution of sea ice thickness}

Maps of the 'climatological' mean sea ice thickness in both fall (Nov-Dec) and spring (Mar-Apr), over the full data period 2003-2016, are illustrated in Fig. 5. The seasonal cycle of the ice thickness within different regions of the ECA is summarized in Table 2. The fall pattern of ice thickness reflects the north to south progression of freeze-up within the HBC and Baffin Bay, with the thickest ice located in the Northwater \& Jones Sound $(1.01 \pm 0.53 \mathrm{~m}$; SR9) and Foxe Basin $\left(\overline{h_{i}}=0.70 \pm 0.44 \mathrm{~m}\right.$; SR6). The thinnest ice is located in the partially frozen Eastern Hudson Bay $(0.13 \pm 0.09 \mathrm{~m}$; SR3), James Bay $(0.25 \pm 0.18 \mathrm{~m}$; SR4) and in the Labrador Sea $(0.38 \pm 0.37 \mathrm{~m}$; SR12). The ice cover in the ECA experiences rapid growth between November and February (average of $25-40 \mathrm{~cm} \mathrm{mo}^{-1}$ ) before slowing $\left(5-20 \mathrm{~cm} \mathrm{mo}{ }^{-1}\right)$ thereafter. However, the average growth rate is $15 \mathrm{~cm} \mathrm{mo}^{-1}$ (80\%) higher in the Hudson Bay Complex (SR1-7) than in Baffin Bay and the Labrador Sea (SR9-12). Throughout winter the thickest sea ice is found in Foxe Basin, which has an average maximum thickness of $1.99 \pm 1.33 \mathrm{~m}$ in spring, whereas after January the thinnest ice is located in Eastern Baffin Bay (SR11), which has the lowest maximum thickness of $1.00 \pm 0.61 \mathrm{~m}$.

The average random uncertainties are generally higher in fall $(\bar{\sigma}=0.15 \mathrm{~m} ; 33 \%)$ than in spring $(\bar{\sigma}=0.08 \mathrm{~m} ; 6 \%)$, due to the bias associated with CS-2 data when the ice is very thin and the higher uncertainty associated with the SMOS data used between November and January (Fig. 5). The minimum random uncertainty of gridded altimeter observations in spring is $0.03 \mathrm{~m}$, typical of most of Hudson Bay and large areas of Baffin Bay and the Labrador Sea. Uncertainty is higher in coastal areas and smaller bays, including Foxe Basin, Hudson Strait and James Bay, where sea surface variability was characteristically higher and only SARIn CS-2 data (with higher speckle noise) were available (Fig. 5d).

East-west asymmetry in mean spring ice thickness is evident across both Hudson and Baffin Bays, but in opposing directions (Fig. 5b). There is a gradual increase in thickness from $1.17 \mathrm{~m}$ in Northwestern Hudson Bay (SR1) to $1.34 \mathrm{~m}$ in Central Hudson Bay (SR2) and finally to $1.54 \mathrm{~m}$ in Eastern Hudson Bay (SR3). This supports the existing hypothesis that sea ice in Hudson Bay has a characteristic northwest-tosoutheast asymmetry in thickness (Saucier et al., 2004), (Gagnon and Gough, 2006), (Joly et al., 2011). In contrast, spring ice thickness decreases from $1.20 \mathrm{~m}$ in Western Baffin Bay (SR10) to $1.00 \mathrm{~m}$ in Eastern Baffin Bay (SR11). This also supports past observations that sea ice in Baffin Bay has a characteristic east-to-west asymmetry in thickness (Valeur et al., 1996).

To evaluate whether these characteristically asymmetrical ice thickness distributions occur every year, and whether the strength of the asymmetry varies between years, we calculated an asymmetry parameter for each spring between 2003 and 2016. The parameter $d \overline{h_{i}} / d x$ was calculated from the change in mean thickness across the $\sim 750 \mathrm{~km}$ distance from SR1 to SR3 in Hudson Bay or the $\sim 300 \mathrm{~km}$ distance from SR10 to SR11 in Baffin Bay. Fig. 6a shows that the parameter clearly varies on an interannual basis, while Fig. $6 \mathrm{~b}$ shows that a significant portion of this variability can be attributed to variability in ice thickness in Eastern Hudson Bay (SR3) and Western Baffin Bay (SR10). There is also an apparent shift in the Baffin Bay ice thickness distribution from strongly asymmetrical during the ICESat period (2003-2008) to weakly asymmetrical during the CS-2 period (2011-2016). The reliability of this observation, as well as potential implications of the shift, will be discussed in more detail in Section 3.2. Fig. 5c-d demonstrate two years with distinctive and opposing spring ice thickness anomaly distributions in the ECA. For instance, the westeast asymmetry was particularly strong $(11 \mathrm{~cm}$ per $100 \mathrm{~km})$ in Hudson Bay but weak ( $-1 \mathrm{~cm}$ per $100 \mathrm{~km}$ ) in Baffin Bay in 2014 (Figs. 6d and 5). Conversely, in 2007 negative ice thickness anomalies in Central and Eastern Hudson Bay led to very little change in ice thickness $(1 \mathrm{~cm}$ per $100 \mathrm{~km}$ ) across Hudson Bay, but positive anomalies in Western Baffin Bay led to strong ice thickness asymmetry across Baffin Bay (Fig. 6c). Although spring ice thickness asymmetry contrasted between the two bays during these years, we found no significant correlation or anticorrelation between Hudson Bay and Baffin Bay asymmetry parameters over the study period.

Areas of thin ice are observed during spring in known polynya locations, such as in North Western Hudson Bay, in the Northwater, and around Southampton, Coats and Mansel Islands in the Hudson Bay Narrows (SR5). While Northwestern Hudson Bay is among the first regions of the ECA to freeze-up during fall (Fig. 5a) (Gagnon and Gough, 2005) and the ice grows rapidly during November, December and January $\left(0.31 \mathrm{~m} \mathrm{mo}^{-1}\right)$, it contains the thinnest sea ice of any region within the Hudson Bay Complex between February and April, coinciding with a $65 \%$ reduction in the ice growth rate $\left(0.11 \mathrm{~m} \mathrm{mo}^{-1}\right)$. This lends support to the hypothesis that the Northwestern Hudson Bay polynya acts as an 'ice factory', where ice grows thermodynamically before it is exported to the south and east by winds, precluding the development of thick ice. It has been suggested that a significant amount of ice in the HBC cannot be accounted for within models without the existence of this polynya (Prinsenberg, 1988). For example, there was a large opening of the northwestern Hudson Bay polynya during April 2014 (Fig. 7). Looking at ice thickness distributions for Sub-Regions 1-3 during this month we find a strong west to east gradient in the modal ice thickness from 0.6 to $1.4 \mathrm{~m}$. Furthermore, there is a thick, clearly dynamically-grown secondary peak between 4 and $8 \mathrm{~m}$ in Eastern Hudson Bay. This feature is the result of ice being dynamically deformed as it is pushed up against the eastern boundary of Hudson Bay. Extended tails with secondary modes are also observed in 
(a)

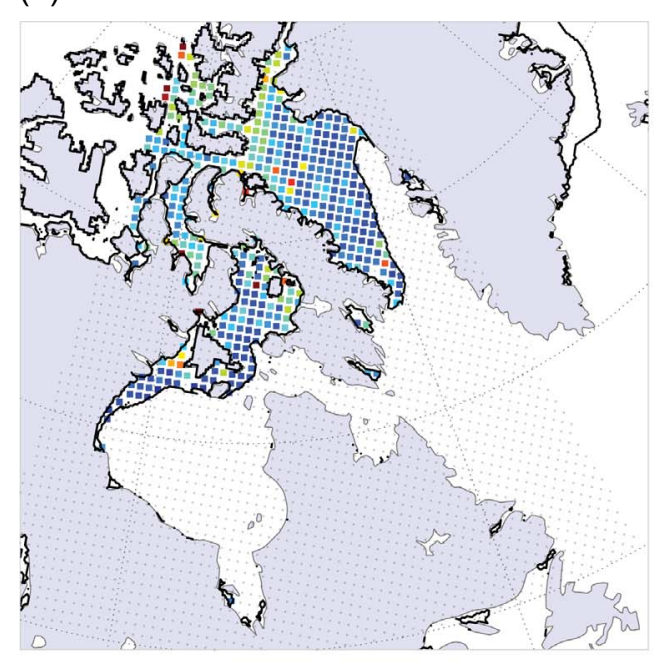

(c) November Uncertainty

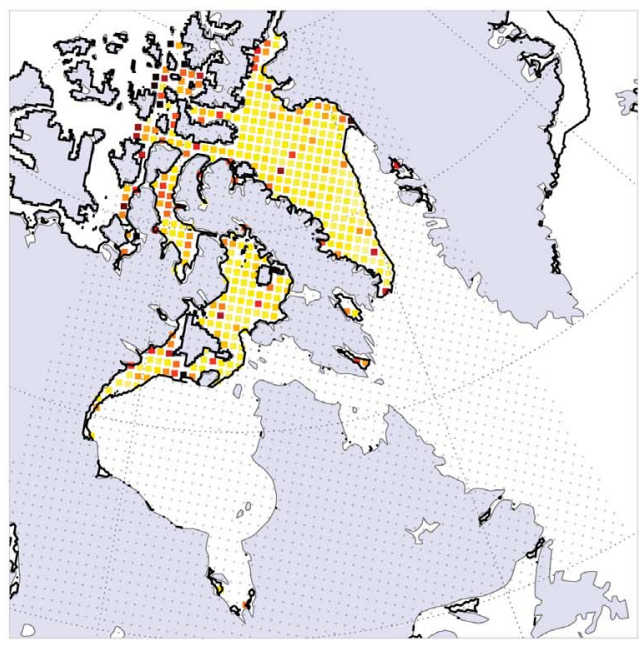

(b)

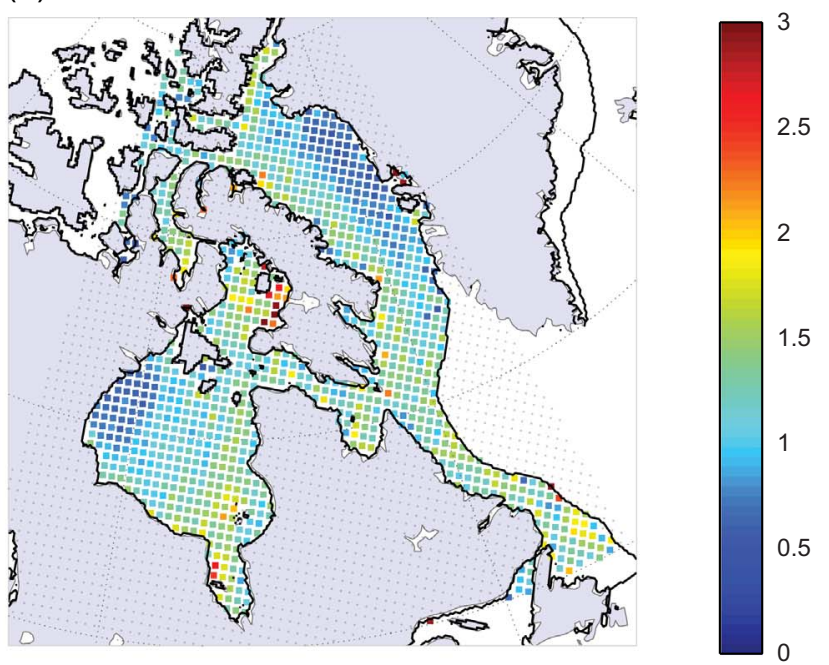

(d) March Uncertainty

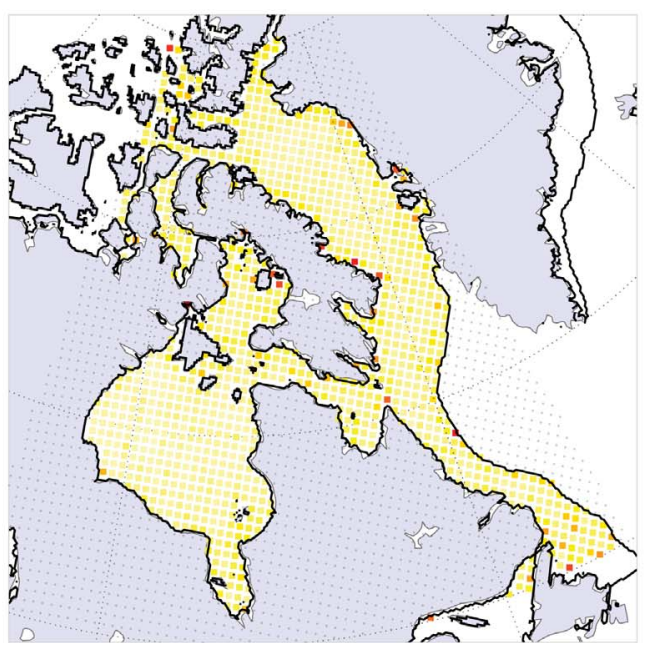

Uncertainty [m]

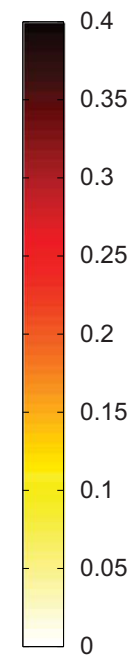

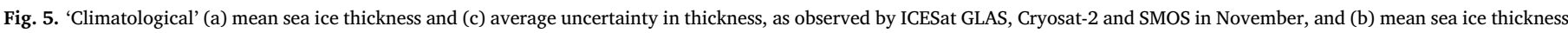

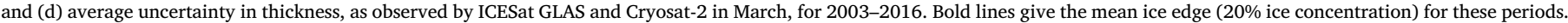

the distributions for Hudson Strait, Foxe Basin and to a lesser extent in the Narrows, while there are essentially no extended tails in Northwestern and Central Hudson Bay, and James Bay, indicating very little dynamic thickening in these regions. The secondary mode of thick ice in the Foxe Basin distribution helps to explain why this region contains the thickest ice within the ECA in spring (Table 2), despite other regions having higher latitude.

Extended tails are not present within the April 2014 ice thickness distributions for Baffin Bay and the Labrador Sea (SR10-12). However, there is a slight extended tail present within the Northwater and Jones Sound (SR9) which we attribute to thick multi-year ice entering Baffin Bay from the central Arctic through Nares Strait (Kwok, 2005). Overall, at least in 2014, it appears that the ice pack within Baffin Bay underwent very little dynamic thickening and was predominantly the result of in situ thermodynamic ice growth.

Table 2

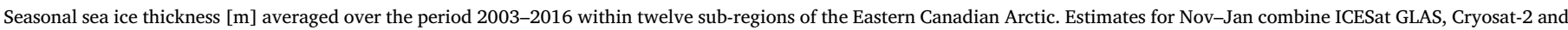
SMOS data, whereas estimates for Feb-Apr combine only the altimeter datasets. Change in ice thickness per month [m mo $\left.{ }^{-1}\right]$ is provided in the final row.

\begin{tabular}{|c|c|c|c|c|c|c|c|c|c|c|c|c|}
\hline \multirow[b]{2}{*}{ Region } & \multicolumn{12}{|c|}{ Sea ice thickness [m] } \\
\hline & 1 & 2 & 3 & 4 & 5 & 6 & 7 & 8 & 9 & 10 & 11 & 12 \\
\hline Nov & 0.28 & 0 & 0 & 0.06 & 0.14 & 0.60 & 0.12 & 1.11 & 1.09 & 0.70 & 0.49 & 0.28 \\
\hline Dec & 0.39 & 0.44 & 0.25 & 0.45 & 0.51 & 0.81 & 0.46 & 1.30 & 0.93 & 0.83 & 0.51 & 0.48 \\
\hline Jan & 0.90 & 0.93 & 0.84 & 0.79 & 0.80 & 1.40 & 0.77 & 1.40 & 1.15 & 0.75 & 0.61 & 0.60 \\
\hline Feb & 1.03 & 1.15 & 1.35 & 1.65 & 1.22 & 1.70 & 1.29 & 1.46 & 1.47 & 1.28 & 0.87 & 1.49 \\
\hline Mar & 1.09 & 1.25 & 1.41 & 1.66 & 1.26 & 1.86 & 1.49 & 1.48 & 1.72 & 1.22 & 0.97 & 1.35 \\
\hline Apr & 1.25 & 1.44 & 1.67 & 1.44 & 1.43 & 2.12 & 1.59 & 1.66 & 1.57 & 1.18 & 1.03 & 1.35 \\
\hline $\mathrm{m} \mathrm{mo}^{-1}$ & 0.20 & 0.28 & 0.35 & 0.33 & 0.26 & 0.32 & 0.31 & 0.10 & 0.15 & 0.12 & 0.12 & 0.25 \\
\hline
\end{tabular}


(a)

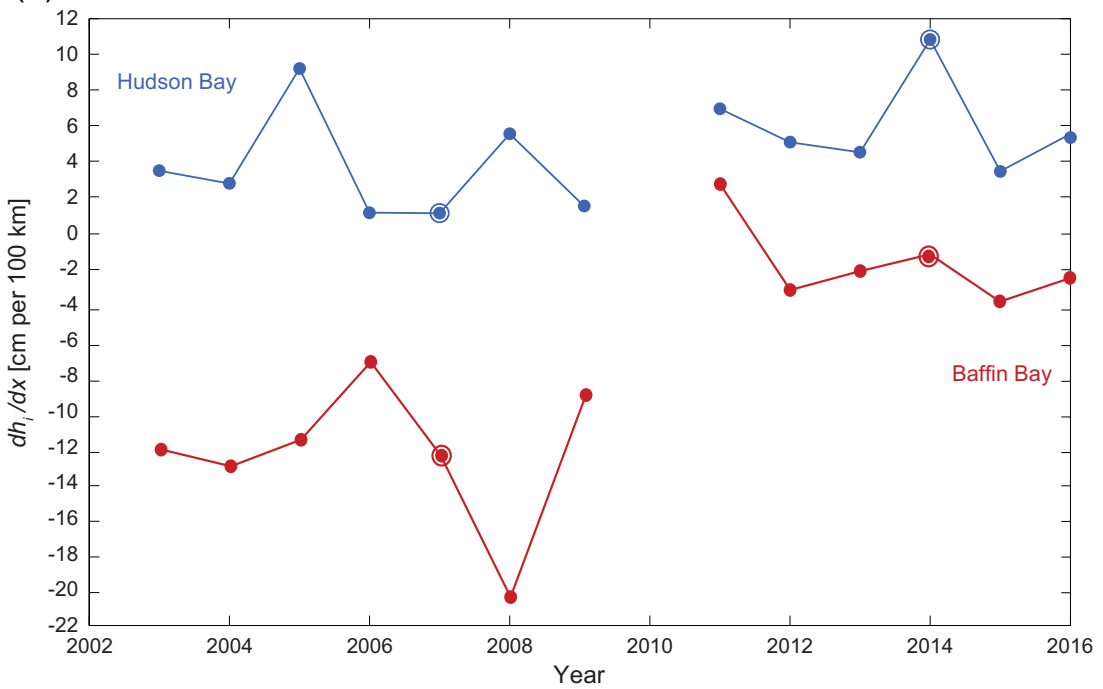

(b)
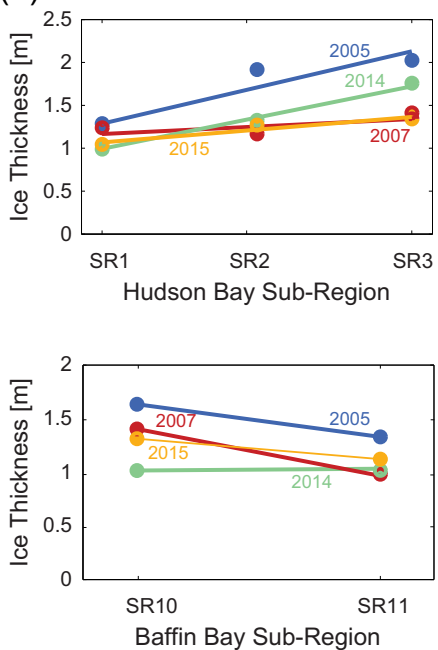

(c)

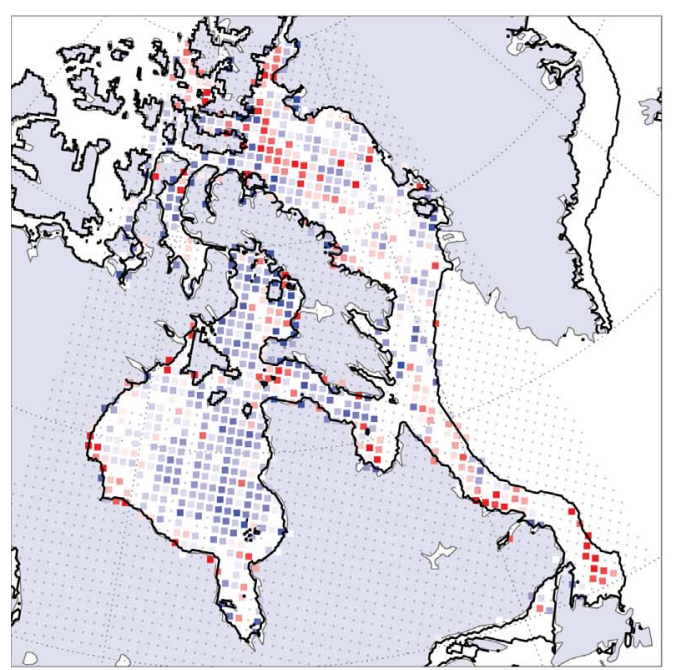

(d)

March 2014
Thickness Anomaly [m]

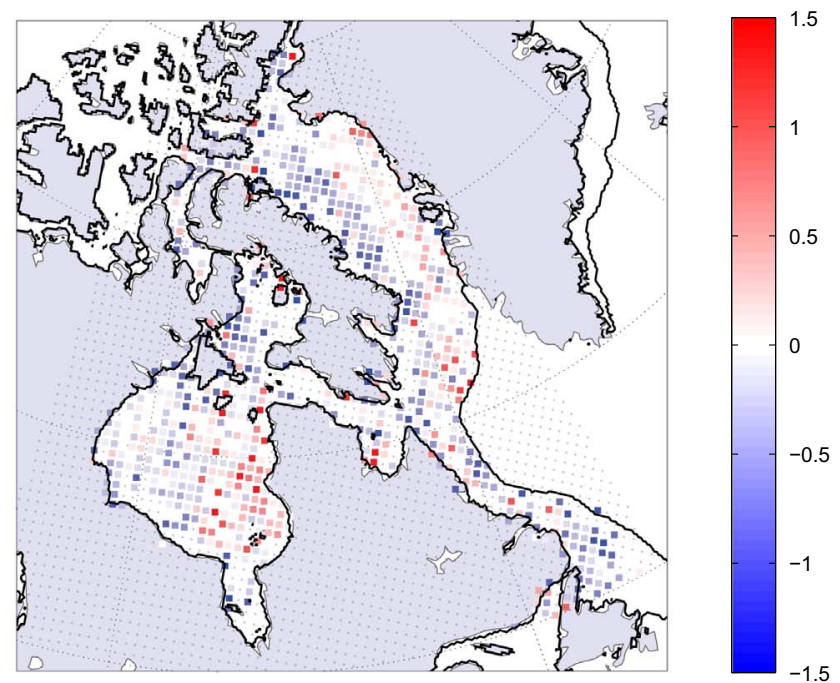

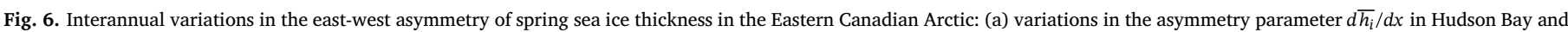

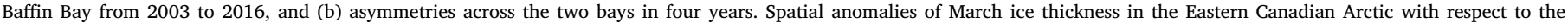

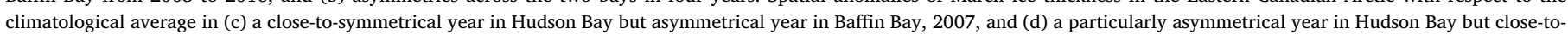
symmetrical year in Baffin Bay, 2014. Bold lines give the mean ice edge (20\% ice concentration).

\subsection{Interannual variability of sea ice thickness and volume}

Time-series of March ice thickness for the total ECA, and for five groups of sub-regions, are shown in Fig. 8. Over the study period, the average end-of-winter ice thickness for the entire ECA varied from a low of $1.08 \mathrm{~m}$ in 2007 to highs of $1.72 \mathrm{~m}$ in 2005 and $1.55 \mathrm{~m}$ in 2013. The 2013 anomaly is primarily due to thicker ice in the HBC, while ice thickness in Western and Eastern Baffin Bay varied little from other years during 2013. The sea ice cover was particularly thick in 2005, with a relative peak in ice thickness evident in all nine sub-regions, excluding Northwestern Hudson Bay which exhibited less interannual variability than other regions throughout the study period. This observed thickening coincided with a particularly strong overall thickening of the Arctic first-year ice cover in 2005 (Kwok et al., 2009). Variations in the standard deviation of ice thickness observations (error bars in Fig. 8) illustrate that it is not only the mean thickness but also the ice thickness distribution that changes between years. For instance, the standard deviations of ice thickness in March 2005, 2013 and 2015 were $>80 \%$ higher than those in March 2009 and 2014. This observation further supports the notion that ice dynamics play a key role in shaping the frequency distribution of ice thickness in the Eastern Canadian Arctic (Fig. 7; see Section 4.1). Trends in sea ice thickness were negative over the entire study period (Fig. 8), although decreasing from $-3.5 \mathrm{~cm} \mathrm{yr}^{-1} \quad(p=0.21)$ during the ICESat record to $-0.5 \mathrm{~cm} \mathrm{yr}^{-1}(p=0.89)$ during the CS-2 record. The monthly-averaged sea ice volume increases in all sub-regions of the ECA over the ice growth season, with a net production of $565 \mathrm{~km}^{3} \mathrm{mo}^{-1}$ (Table 3). Within the Hudson Bay Complex (SR1-7) ice volume increases at an average rate of $328 \mathrm{~km}^{3} \mathrm{mo}^{-1}$. The highest growth rate of $486 \mathrm{~km}^{3} \mathrm{mo}^{-1}$ occurs during January as the remaining portions of Southeastern Hudson Bay freeze-up and thermodynamic growth accelerates in Northwestern Hudson Bay with cooling temperatures. We observe a decline in the ice volume between March and April in James Bay, which is likely caused by earlier melt onset relative to the greater HBC (Markus et al., 2009). Around 28\% of the spring ice volume within the HBC is contained within Central Hudson Bay (SR2), which has the highest rate of ice production $\left(94 \mathrm{~km}^{3} \mathrm{mo}^{-1}\right)$. However, despite having an area almost one third the size of SR2, Eastern Hudson Bay (SR3) still 


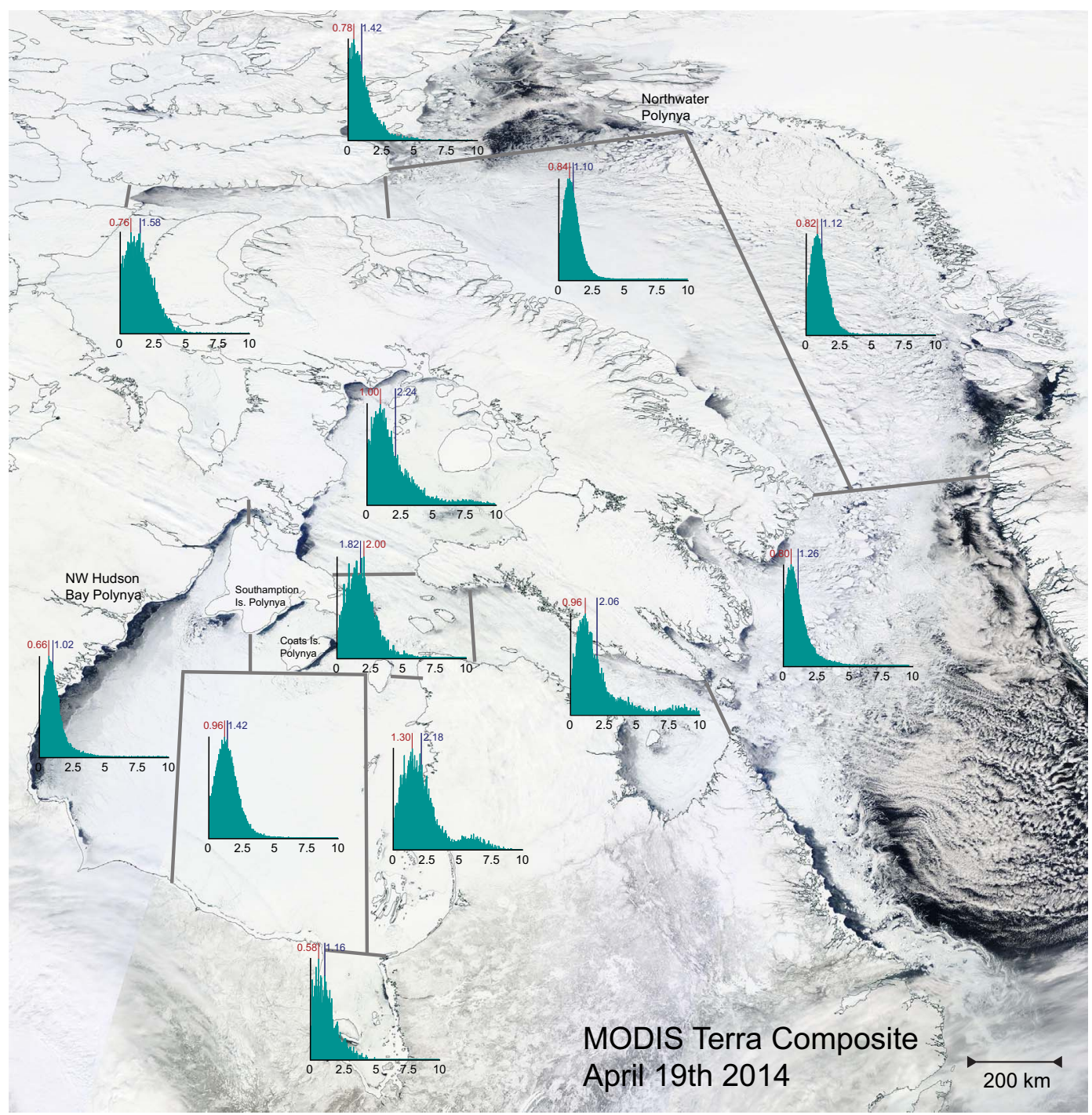

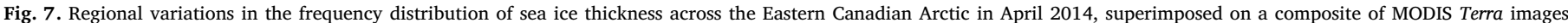

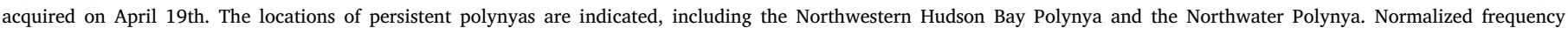

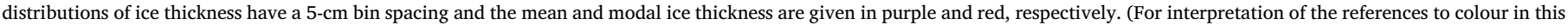
figure legend, the reader is referred to the web version of this article.)

contributes $13 \%$ of the spring ice volume within the $\mathrm{HBC}$, due to its long tail of dynamically thickened ice (Fig. 6).

In the Baffin Bay Complex (SR9-12) ice volume increases at an average rate of $211 \mathrm{~km}^{3} \mathrm{mo}^{-1}$, although the highest growth rate of $604 \mathrm{~km}^{3} \mathrm{mo}^{-1}$ occurs in February, a month later than in Hudson Bay. This is because the southern parts of Baffin Bay and Labrador Sea only start to freeze-up in January-February, when air temperatures reach their annual minimum (Tang et al., 2004). The significant loss of ice volume $\left(-75 \mathrm{~km}^{3} \mathrm{mo}^{-1}\right)$ in the Labrador Sea between March and April (Table 3) can be attributed to stronger southward ice export than replenishment from Baffin Bay and Hudson Strait (Valeur et al., 1996).

The seasonal progression of ice volume within the ECA can be

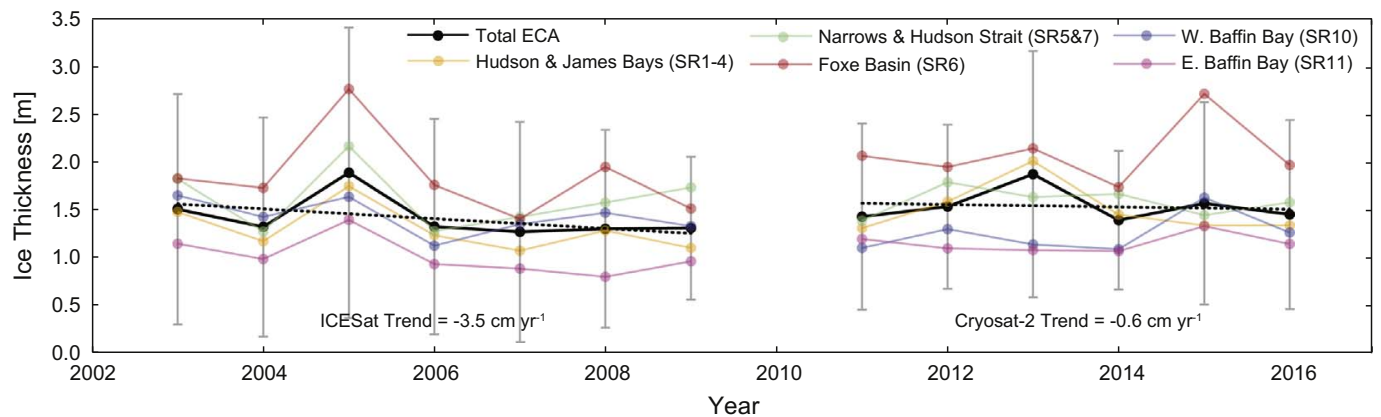

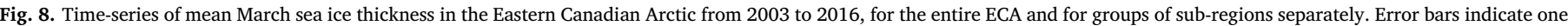

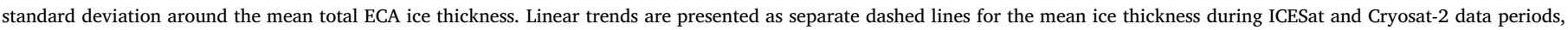
although neither is statistically significant. 
Table 3

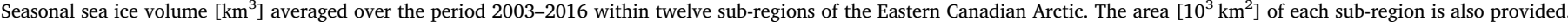

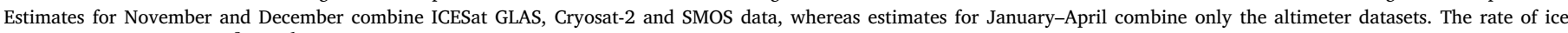
production per month $\left[\mathrm{km}^{3} \mathrm{mo}^{-1}\right]$ is provided in the final row.

\begin{tabular}{|c|c|c|c|c|c|c|c|c|c|c|c|c|}
\hline \multirow[b]{2}{*}{ Region } & \multicolumn{12}{|c|}{ Sea ice volume $\left[\mathrm{km}^{3}\right]$} \\
\hline & 1 & 2 & 3 & 4 & 5 & 6 & 7 & 8 & 9 & 10 & 11 & 12 \\
\hline Area & 275 & 333 & 128 & 63 & 90 & 183 & 178 & 253 & 125 & 310 & 303 & 1160 \\
\hline Nov & 36 & 0 & 0 & 2 & 6 & 75 & 2 & 231 & 92 & 152 & 23 & 10 \\
\hline Dec & 82 & 108 & 22 & 15 & 27 & 127 & 36 & 305 & 82 & 222 & 98 & 46 \\
\hline Jan & 184 & 289 & 95 & 40 & 50 & 172 & 72 & 311 & 94 & 205 & 142 & 150 \\
\hline Feb & 249 & 349 & 148 & 94 & 99 & 241 & 189 & 328 & 127 & 347 & 213 & 508 \\
\hline Mar & 252 & 397 & 159 & 103 & 104 & 285 & 213 & 332 & 162 & 342 & 254 & 500 \\
\hline Apr & 256 & 471 & 173 & 89 & 115 & 341 & 221 & 394 & 147 & 316 & 259 & 425 \\
\hline $\mathrm{km}^{3} \mathrm{mo}^{-1}$ & 48 & 94 & 38 & 22 & 24 & 54 & 50 & 26 & 16 & 38 & 49 & 108 \\
\hline
\end{tabular}

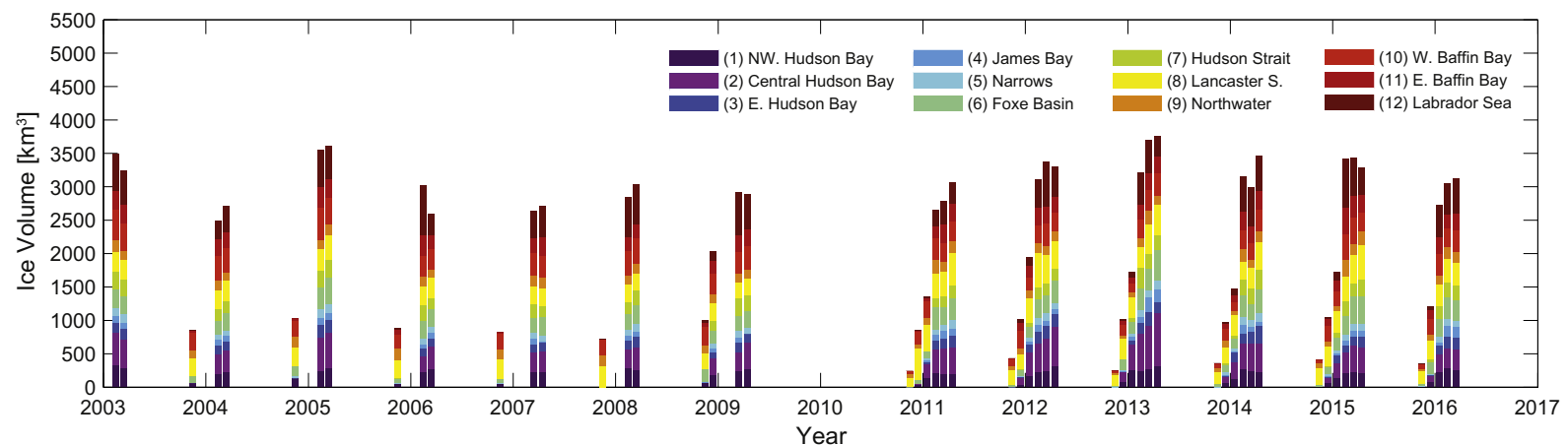

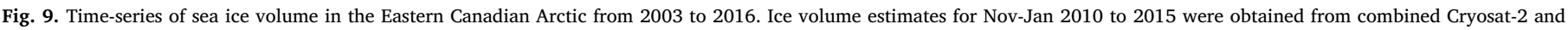
SMOS ice thickness data.

Table 4

Mean kinematic parameters of the ice motion field in Hudson Bay (SR1-3) between December and April for all coinciding years with ICESat-2 and Cryosat-2 observations. Years with exceptionally asymmetrical east-west ice thickness distributions are highlighted in red and exceptionally level thickness distributions in blue.

\begin{tabular}{|c|c|c|c|c|c|c|}
\hline & $\begin{array}{l}\text { Speed }[\mathrm{km} \\
\left.\text { day }^{-1}\right]\end{array}$ & $\begin{array}{l}\text { Direction } \\
\left({ }^{\circ} \text { from } N\right)\end{array}$ & $\begin{array}{l}\text { W-E velocity } \\
{\left[\mathrm{km} \mathrm{day}^{-1}\right]}\end{array}$ & $\begin{array}{l}\text { Divergence } \\
{\left[10^{-3} \text { day }^{-1}\right]}\end{array}$ & $\begin{array}{l}\text { Vorticity } \\
{\left[10^{-3} \text { day }^{-1}\right]}\end{array}$ & $\begin{array}{l}\text { Shear }\left[10^{-3}\right. \\
\left.\text { day }^{-1}\right]\end{array}$ \\
\hline & $\sqrt{u^{2}+v^{2}}$ & & $(u, v)_{e a s t}$ & $\frac{\left(u_{x}+v_{y}\right)}{2}$ & $\frac{\left(v_{x}-u_{y}\right)}{2}$ & 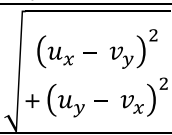 \\
\hline 2003 & 1.45 & 126 & 0.74 & 0.48 & 0.91 & 12.7 \\
\hline 2004 & 1.38 & 123 & 0.83 & 0.57 & 0.59 & 12.2 \\
\hline 2005 & 1.37 & 123 & 0.81 & 0.60 & 0.90 & 11.7 \\
\hline 2006 & 1.14 & 136 & 0.51 & 0.92 & 0.16 & 12.1 \\
\hline 2007 & 1.24 & 128 & 0.75 & 0.82 & 0.35 & 12.8 \\
\hline 2008 & 1.31 & 117 & 0.81 & 0.53 & 0.90 & 11.5 \\
\hline 2011 & 1.50 & 111 & 1.21 & 0.38 & 1.02 & 12.1 \\
\hline 2012 & 0.88 & 116 & 0.64 & 0.00 & 0.24 & 11.1 \\
\hline 2013 & 1.03 & 122 & 0.72 & 0.82 & 0.38 & 13.7 \\
\hline 2014 & 1.63 & 114 & 1.24 & 0.50 & 0.99 & 12.9 \\
\hline 2015 & 1.52 & 111 & 1.12 & 0.22 & 0.84 & 11.3 \\
\hline Ave & 1.31 & 121 & 0.85 & 0.53 & 0.66 & 12.19 \\
\hline
\end{tabular}

observed from the combined CS-2 and SMOS data for 2010-2016 in Fig. 9. Sea ice is generally only present in restricted portions of Hudson Bay and Baffin Bay, as well as Foxe Basin, Lancaster Sound \& the Gulf of Boothia and the Northwater \& Jones Sound, in November and December. Significant ice production occurs in Eastern Hudson Bay \& James Bay, Hudson Strait, and Baffin Bay \& the Labrador Sea between January and March. By focusing on a few sub-regions independently, it is noticeable that ice volume appears to occasionally decrease between successive months. For instance, ice volume in Hudson Strait dropped by $20-70 \mathrm{~km}^{3}$ between February and March in 2013 and 2014. Within Northwestern Hudson Bay, the Narrows, Hudson Strait and the Northwater the decrease in ice volume can be explained by the formation of polynyas along the coast and areas of open water within the ice pack (e.g. Fig. 7). In Hudson Bay these polynyas are maintained by northwesterly winds that advect the existing ice cover eastwards (Section 4.1).

\section{Discussion}

\subsection{Role of ice dynamics in shaping the Hudson and Baffin Bay ice thickness distributions}

The characteristically asymmetrical east-west distributions of sea ice thickness in Hudson Bay and Baffin Bay during spring (Fig. 5b) suggest that ice dynamics could play an important role in shaping the ice cover in both of these regions. For instance, end-of-spring ice 
thickness is around $0.5-1.0 \mathrm{~m}$ in Northwestern Hudson Bay, while in contrast in Eastern Hudson Bay it is generally 1.5-2.0 m, with several zones $>2 \mathrm{~m}$. This implies that in the former the ice is mainly thermodynamically grown and thus relatively young (Granskog et al., 2011) and that significant dynamic redistribution of thinner floes into thicker ice occurs in the latter (Prinsenberg, 1988). Dynamic ice redistribution is driven by the deformation of and between drifting ice floes, such that kinematic parameters of the ice motion field (divergence, vorticity and/or shear) could explain, at least partially, interannual variations in Hudson Bay and Baffin Bay ice thickness asymmetry. December to April averages of these parameters (i.e. for the total ice growth season) within Hudson Bay, for each year with ICESat or CS2 observations, are presented in Table 4.

In Hudson Bay, the mean ice drift speed for the December-April period is $1.31 \mathrm{~km} \mathrm{day}^{-1}$ in a southeast direction $\left(121^{\circ}\right)$, with a mean west-east drift velocity of $0.85 \mathrm{~km} \mathrm{day}^{-1}$ (Table 4). All yearly December-April west-east drift velocities are positive, reflecting the fact that mean drift directions do not vary considerably from southeast (ranging from 111 to $136^{\circ}$ ). The units of the kinematic parameters are day $^{-1}$, because they characterize (unitless) meter per meter deformation of the ice pack; however, average divergence and vorticity are more than an order of magnitude smaller than shear. Mean ice vorticity is above zero in every year, consistent with the predominantly cyclonic ice motion in Hudson Bay (Fig. 10a) and convergence of the ice pack (Hochheim et al., 2011). Finally, the mean ice drift velocities into (+) or out of $(-)$ sub-regions 1,2 and 3 over the full study period are $-0.53,+0.30$ and $+0.55 \mathrm{~km} \mathrm{day}^{-1}$, respectively. This observation is aligned with sea ice being characteristically exported from Northwestern Hudson Bay after it forms, whereupon it drifts east into central Hudson Bay and converges in Eastern Hudson Bay. As originally suggested in Section 3.2, this would explain the secondary mode of very thick ice in the 2014 eastern Hudson Bay thickness distribution (Fig. 7) and the west-east asymmetry in the spring mean ice thickness (Fig. 5b).

In Baffin Bay, the mean ice drift speed for the December-January period is $4.03 \mathrm{~km} \mathrm{day}^{-1}$, more than three times the speed of ice drift in Hudson Bay, in a south-southeast direction $\left(147^{\circ}\right)$. Given the predominantly southward drift of ice in Baffin Bay, the mean west-east drift velocity of $1.78 \mathrm{~km}$ day $^{-1}$ represents a smaller fraction of total ice transport than it did in Hudson Bay. In contrast to Hudson Bay, the vorticity in Baffin Bay is negative in every year of the study period, with the exception of 2005 (Fig. 10c), which indicates predominantly anticyclonic ice motion and divergence of the ice pack. Indeed, average values for the divergence parameter between December and April are approximately four times higher in Baffin Bay than in Hudson Bay over the study period. Since ice motion is typically not from the west to the east and is generally divergent, dynamic ice motion occurring within the bay likely cannot explain the west-east asymmetry of ice thickness in Baffin Bay.

To examine the relationship between interannual variations in sea ice motion/deformation and thickness within Hudson Bay, we recursively calculated the correlation coefficient between each of the six parameters in Table 4 and the east-west ice thickness asymmetry parameter $d \overline{h_{i}} / d x$ (Fig. 6a), using varying time intervals to average the kinematic parameters. We discovered that the ice drift direction, the west-east component of the ice drift velocity vector $(u, v)_{\text {east }}$ and the vorticity $\zeta$ are all significantly correlated with $d \overline{h_{i}} / d x$, particularly over the time period from the start of January to the end of March. Fig. 10b illustrates the relationship between the asymmetry and ice vorticity $(r=0.69, \mathrm{p}<0.05)$. A higher vorticity clearly produces a more asymmetrical (i.e. more convergent) ice cover in Hudson Bay, which is illustrated in Table 4. However, we found no relationship between vorticity and ice cover asymmetry in Baffin Bay (Fig. 10c).

The mean ice motion field between January and March 2014 demonstrates that strong cyclonic ice drift leads to negative vorticity (ice divergence) along the coast of Northwestern Hudson Bay and positive vorticity (ice convergence) along the opposite coast in Eastern Hudson Bay (Fig. 10a). Interestingly, the zone of positive vorticity around the Belcher Islands also coincides with particularly high spring ice thickness in 2014 (Fig. 6d). Most of the years studied fit the linear relationship relatively well (Fig. 10b); however, the Hudson Bay ice covers in 2004 and 2015 were less asymmetrical than expected, based on the vorticity, whereas the ice covers in 2005, 2012 and 2014 were more asymmetrical than expected. This implies that factors other than ice dynamics also influence interannual variations in the asymmetry of the Hudson Bay sea ice thickness distribution. Overall, the winterspring ice vorticity can explain just under half (48\%) of the variance in (a)

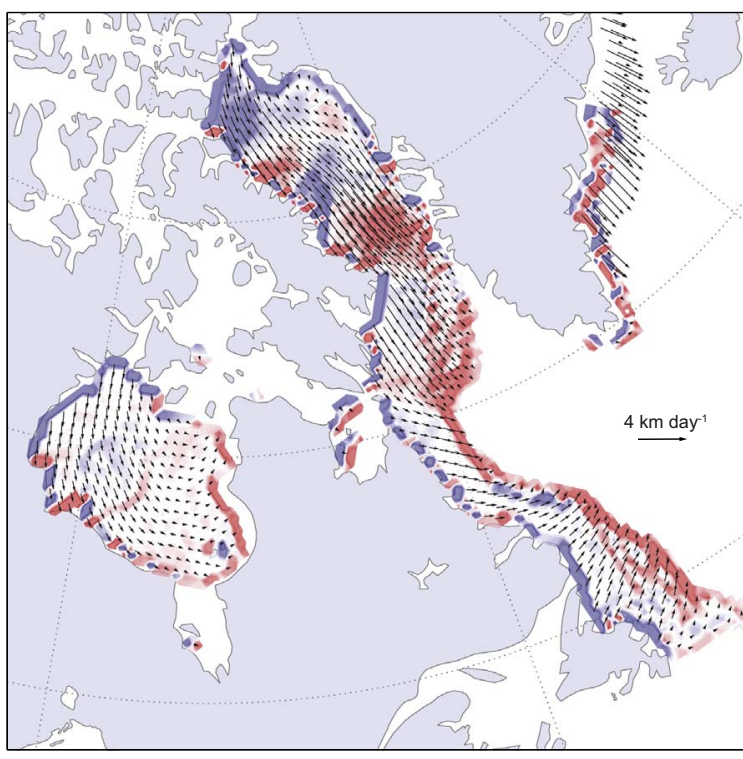

Vorticity [day $\left.{ }^{-1}\right]$

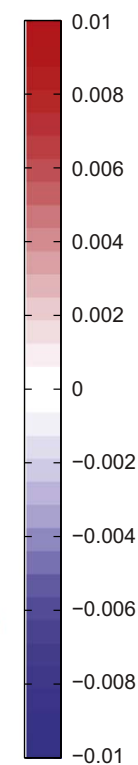

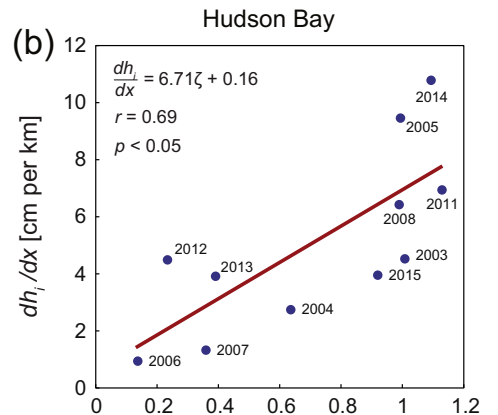

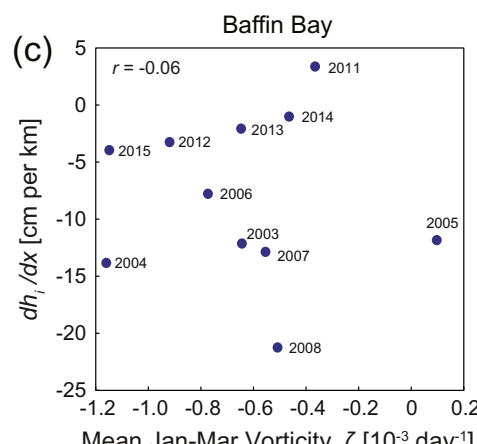

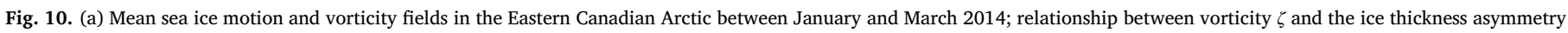
parameter $d \overline{h_{i}} / d x$ in (b) Hudson Bay and (c) Baffin Bay, for the period 2003-2015. 
Table 5

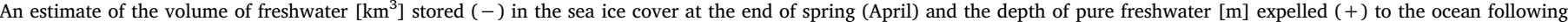
summer melt (assuming ice melts in situ), for the period 2003-2016, within twelve sub-regions of the Eastern Canadian Arctic.

\begin{tabular}{|c|c|c|c|c|c|c|c|c|c|c|c|c|}
\hline Region & 1 & 2 & 3 & 4 & 5 & 6 & 7 & 8 & 9 & 10 & 11 & 12 \\
\hline Spring FW stored $\left[\mathrm{km}^{3}\right]$ & -192 & -352 & -130 & -68 & -88 & -257 & -166 & -304 & -122 & -257 & -188 & -371 \\
\hline Summer FW layer [m] & 0.70 & 1.06 & 1.02 & 1.07 & 0.97 & 1.41 & 0.93 & 1.20 & 0.98 & 0.83 & 0.62 & 0.32 \\
\hline
\end{tabular}

the asymmetry of the spring Hudson Bay ice thickness distribution. This emphasizes the strong role of ice vorticity in regulating the Hudson Bay ice cover, building on the results of (Hochheim et al., 2011) who showed that positive ice vorticity also contributes to negative spring sea ice extent anomalies, particularly in northern Hudson Bay. However, we found only a weak $(r=0.25)$ insignificant relationship between January-March ice vorticity and spring sea ice volume.

Sea ice persisted unusually late into the summer in July 2015, with heavy ice conditions in Eastern Hudson Bay cutting off some communities in Northern Quebec from resupply shipments. It seems intuitive that thicker ice at the end of spring may contribute to such conditions in summer; however, the ice cover in spring 2015 was not uncharacteristically asymmetrical as it was in 2014 or thick as it was in 2005. In fact, we found no clear spatial relationship between the end-ofspring ice thickness distribution and sea ice concentration anomalies in summer.

\subsection{Summer freshwater fluxes}

The freshwater content of Hudson Bay varies as a function of sea ice formation/melt, seasonal changes in river input, precipitation/evaporation, and the rate of freshwater export through Hudson Strait. River discharge contributes an estimated $630-870 \mathrm{~km}^{3} \mathrm{yr}^{-1}$ freshwater to Hudson and James Bays, which corresponds to $12 \%$ of the total panArctic runoff (Saucier et al., 2004), (Lammers et al., 2001), and the net product of precipitation (snow and rain) minus evaporation contributes $220 \mathrm{~km}^{3} \mathrm{yr}^{-1}$ (St-Laurent et al., 2011). In contrast, outflow through Hudson Strait removes an estimated $800-1050 \mathrm{~km}^{3} \mathrm{yr}^{-1}$ freshwater from the basin (Saucier et al., 2004), (St-Laurent et al., 2011). Baffin Bay is less well protected from neighbouring water masses than Hudson Bay. Therefore, the freshwater content of Baffin Bay also varies as a function of sea ice formation/melt, seasonal changes in river and glacial ice input, and precipitation/evaporation, but most importantly freshwater import/export through northern channels including Lancaster Sound, Jones Sound and Davis Strait, as well as through Davis Strait to the south. Precipitation in Baffin Bay is low, contributing only $30 \mathrm{~km}^{3} \mathrm{yr}^{-1}$, and glacial ice contributes an estimated $500 \mathrm{~km}^{3} \mathrm{yr}^{-1}$ (assuming half of the ice melts in the bay) (Tang et al., 2004). The freshwater imported from the northern channels is approximately 920-1460 $\mathrm{km}^{3} \mathrm{yr}^{-1}$, whereas the volume exported through Davis Strait is approximately $3700 \mathrm{~km}^{3} \mathrm{yr}^{-1}$ (Tang et al., 2004). In addition, around $1200 \mathrm{~km}^{3} \mathrm{yr}^{-1}$ of freshwater is transported northward into Baffin Bay from the Labrador Sea on the Greenland Shelf (Cuny et al., 2005). Our observations of sea ice volume allow us to evaluate the remaining component of the freshwater budgets in Hudson and Baffin Bays, i.e. the removal of freshwater from the ocean as sea ice forms in fall and subsequent re-entry to the surface mixed-layer as the ice melts in summer (Landy et al., 2014), albeit potentially in a different location than where it formed.

We developed a climatology of summer/fall (July-October) sea surface salinity in the Eastern Canadian Arctic from 36-km Aquarius observations (available at: http://nsidc.org/data/AQ3_SSS) (Brucker et al., 2015), collected over the period 2011-2014. Surface salinity varied from 25 to 35 psu between different areas of the ECA. These data were then used to estimate the bulk salinity of sea ice forming from the seawater, according to the following ice thickness-dependent salinity parameterization (Ryvlin, 1974):
$S_{i}=S_{w}\left(1-S_{R}\right) e^{-\phi \sqrt{h_{i}}}+S_{R} S_{w}$

where $S_{w}$ is the sea surface salinity (from Aquarius observations), $S_{R}$ is the ratio of the bulk salinity at the end of the ice growth season to standard seawater, taken as 0.175 (Tian-Kunze et al., 2014), and $\phi$ is a growth rate coefficient taken as 0.5 (Ryvlin, 1974). The volume of freshwater stored in the ice was estimated from:

$V_{f w}=V_{i}\left(1-\frac{S_{i}}{33}\right)\left(\frac{\rho_{i}}{\rho_{w}}\right)$.

The reference salinity of seawater in Hudson Bay was taken as 33 psu, following (St-Laurent et al., 2011). Uncertainty in the volume of freshwater was calculated by propagating errors in ice volume and sea surface salinity observations through Eqs. (5) and (6).

Regional variations in the climatological average (2003-2016) volume of freshwater stored in the ECA at the end of spring (April) are provided in Table 5. The volume of freshwater removed from the ocean through ice formation within the Hudson Bay Complex (SR1-7) reaches a maximum of $1253 \pm 15 \mathrm{~km}^{3}$ by the end of April. This volume identifies the peak freshwater stored in sea ice before melt onset in May. In Hudson and James Bays, average April $V_{f w}$ stored in the ice cover is $742 \pm 10 \mathrm{~km}^{3}$, which is approximately $100 \mathrm{~km}^{3}$ higher than the model prediction of (St-Laurent et al., 2011). This supports the assertion of (Prinsenberg, 1988) that typical estimates for the freshwater content of Hudson Bay miss the contribution from the very thick tail-end of the ice thickness distribution, i.e. from pressure ridges, which is included in our observations. The volume of freshwater stored within the sea ice cover in Baffin Bay (SR10-11) reaches a maximum of $445 \pm 5 \mathrm{~km}^{3}$ by the end of April, which is similar to the estimated total annual export of ice through Davis Strait (Cuny, Rhines, and Kwok, 2005). The freshwater volume per unit area (yield) which can potentially be expelled to the ocean during summer ice melt is largest in Foxe Basin at $1.41 \mathrm{~m}$, since the thickest ice within the ECA is found in this region, whereas it is smallest Northwestern Hudson Bay, Western Baffin Bay and the Labrador Sea at 0.70, 0.62 and $0.32 \mathrm{~m}$, respectively (Table 5). However, this assumes that the ice cover melts in situ and is not redistributed across the bay while it melt between April and July.

When integrated over the entire Hudson Bay Complex, the thickness of this fresh meltwater 'layer' varies from a low of $0.82 \mathrm{~m}$ in 2011 to a high of $1.15 \mathrm{~m}$ in 2005 , corresponding to $-10 \%$ and $+27 \%$ of the 2003-2016 average, respectively. The anomalously high freshwater volume stored within the Hudson Bay ice cover in 2005 may explain the strong sea ice melt but weak river water signals present during fall 2005 in Central Hudson Bay, as observed by (Granskog et al., 2011). Indeed, the volume of freshwater contained within the ice cover in SR2 at the end of spring 2005 was $>100 \mathrm{~km}^{3}$ higher than the long-term average (Table 5). When integrated over Baffin Bay, the thickness of the fresh meltwater layer varies with a similar magnitude to the Hudson Bay Complex, from a low of $0.62 \mathrm{~m}$ in 2014 to a high of $0.88 \mathrm{~m}$ in 2005, corresponding to $-14 \%$ and $+22 \%$ of the $2003-2016$ average, respectively. The respective standard deviations of the volumes of freshwater stored in the Hudson Bay Complex and Baffin Bay ice covers are 171 and $51 \mathrm{~km}^{3}$.

One implication of these strong interannual variations in freshwater storage is that the volume of freshwater available during summer for outflow to the Labrador Sea varies between years (Myers et al., 1990), (St-Laurent et al., 2011). The sensitivity of the freshwater budget to 
interannual variations in spring sea ice volume can be calculated by assuming constant estimates for river discharge, glacial ice input, precipitation minus evaporation, and total inflow/outflow from neighbouring water masses, as outlined above. We estimate that the available summer freshwater varies by $\pm 14 \%$ depending on interannual variations in the volume of the Hudson Bay Complex ice cover and by $\pm 16 \%$ depending on variations in the Baffin Bay ice cover. This could have significant repercussions for stratification, water mass properties and productivity downstream in the Labrador Sea (Déry et al., 2011), (Granskog et al., 2011).

\section{Conclusions}

In this study we have presented a climatology of sea ice thickness observations in the Eastern Canadian Arctic for the period 2003-2016, bridging the sampling intervals of the laser altimeter ICESat and the radar altimeter Cryosat-2. Very few in situ ice thickness observations exist for the ECA that would allow us to elucidate thickness patterns and trends. Our satellite-derived results demonstrate that sea ice thickness is characteristically asymmetrical in both Hudson and Baffin Bays, but in opposing directions. The spring ice cover is $40 \mathrm{~cm}$ thicker in northwestern compared to eastern Hudson Bay, and $20 \mathrm{~cm}$ thicker in western compared to eastern Baffin Bay. However, the level of west-east asymmetry varies considerably on an interannual basis, ranging from 2 to $11 \mathrm{~cm}$ per $100 \mathrm{~km}$ in Hudson Bay and from -21 to $2 \mathrm{~cm}$ per $100 \mathrm{~km}$ in Baffin Bay. In spring, the thinnest ice is located in Eastern Baffin Bay $\left(\overline{h_{i}}=1.00\right)$ and in Northwestern Hudson Bay $\left(\overline{h_{i}}=1.17\right)$, where a large and persistent polynya frequently develops. The thickest ice $\left(\overline{h_{i}}=1.99\right)$ is located in Foxe Basin, where ice formation begins early in fall and ice dynamics contribute to extending the upper tail of the ice thickness distribution. By integrating the ice thickness observations with ice concentration data, we calculated that the mean sea ice growth rate within the Eastern Canadian Arctic from November to April is $565 \mathrm{~km}^{3} \mathrm{mo}^{-1}$, with the ice thickening most rapidly in Eastern Hudson Bay (where strong convergence encourages dynamic growth and ridging). Several latent heat polynyas within the ECA, specifically in Northwestern Hudson Bay, may not contain thick ice by the end of winter but still contribute significantly to the overall ice production.

By examining kinematic parameters of the ice motion field within Hudson Bay, we found a statistically significant positive relationship between the January-March vorticity of the ice pack and the spring ice thickness asymmetry $(r=0.69)$. Increasingly positive vorticity indicates cyclonic ice motion and convergence of ice within the bay. Based on this relationship, a $20 \%$ increase in vorticity enhances the ice thickness asymmetry by approximately $1 \mathrm{~cm}$ per $100 \mathrm{~km}$ in the west to east direction. Winter ice vorticity is generally negative in Baffin Bay, which indicates anticyclonic ice motion and divergence of ice within the bay, and perhaps as a consequence we found no statistical relationship between the vorticity and spring ice thickness asymmetry. The combined altimeter datasets also appear to show that the ice thickness distribution in Baffin Bay has become progressively less asymmetrical over the past decade due, in particular, to declining sea ice thickness on the western side of the bay.

Finally, our results suggest that the freshwater yield during summer from melting sea ice would be highest in Foxe Basin (around $1.4 \mathrm{~m}$ ) and lowest in Northwestern Hudson Bay, Eastern Baffin Bay and the Labrador Sea $(0.3-0.7 \mathrm{~m})$. However, owing to strong interannual variations in spring ice volume, the depth of the freshwater layer at the ocean surface in summer, after all the sea ice has melted, can vary by tens of centimeters. The implication of this variability is that the volume of freshwater within the Eastern Canadian Arctic available for outflow south through the Labrador Sea during summer varies by an estimated $\pm 15 \%$ between years.

The prospective launch date for the next major satellite altimeter with a focus on the polar regions is ICESat- 2 in 2017. Data from this satellite could be used to extend the sea ice thickness record presented in this study to 15-20 years, which would enable a more robust statistical evaluation of the ice thickness and volume patterns identified here and potentially long-term trend analysis. Negative trends in ice thickness continuing into the coming decades would undoubtedly influence socioeconomic activities in the ECA. Vessel traffic has more than doubled over the past ten years as thick sea ice has disappeared from the Canadian Arctic and the open water season has lengthened (PEW Charitable Trust, April, 2016). A thinner ice pack throughout the ECA will not only contribute to the continued lengthening of the open water shipping season, but also draw the attention of parties interested in year round shipping to communities and mine sites throughout the ECA. One of the primary northern marine transportation corridors identified by the Canadian Coast Guard is located between the Labrador Sea and the Port of Churchill in Hudson Bay. High-resolution ice thickness observations, such as those presented here, could be used to examine whether interannual variations and/or long-term changes in the quantity of ice at the thickest $(>3 \mathrm{~m}$ ) end of the ice thickness distribution have affected shipping along this and other transportation corridors in the Eastern Canadian Arctic.

\section{Acknowledgements}

This work is a contribution to the Natural Sciences and Engineering Research Council of Canada (NSERC) Collaborative Research and Development (CRD) project: BaySys (contributions of climate change and hydro-electric regulation to the variability and change of freshwater-marine coupling in the Hudson Bay system), undertaken in collaboration with Manitoba Hydro, to ArcticNet Networks of Centres of Excellence (NCE), and to the Arctic Science Partnership (ASP) asp-net. org. Funding for JCL, DB and NT was provided by NSERC, ArcticNet NCE, and the Canada Research Chair (CRC) program.

\section{Appendix A. Supplementary material}

Supplementary data to this article can be found online at http://dx. doi.org/10.1016/j.rse.2017.08.019.

\section{References}

Barber, D.G., Massom, R.A., 2007. The role of sea ice in Arctic and Antarctic Polynyas. In: Smith, W.O., Barber, D.G. (Eds.), Polynyas: Windows to the World. Elsevier Oceanography Series, pp. 1-54.

Brucker, L., Dinnat, E., Koenig, L., 2015. Aquarius L3 Weekly Polar-gridded Sea Surface Salinity, Version 5. Distributed Active Archive Center, Boulder, Colorado USA.

Comiso, J., 2012. Large decadal decline of the Arctic multiyear ice cover. J. Clim. 25, 1176-1193.

Cuny, J., Rhines, P.B., Kwok, R., 2005. Davis Strait volume, freshwater and heat fluxes. Deep Sea Res. Part 1: Oceanogr. Res. Pap. 52 (3), 519-542.

Déry, S.J., Mlynowski, T.J., Hernández-Henríquez, M.A., Straneo, F., 2011. Interannual variability and interdecadal trends in Hudson Bay streamflow. J. Mar. Syst. 88 (3), 341-351.

EUMETSAT, 2015. Global Sea Ice Concentration Reprocessing Dataset 1978-2015, v1.2. Norwegian and Danish Meteorological Institutes.

Farrell, S.L., Laxon, S.W., McAdoo, D.C., Yi, D., Zwally, H.J., 2009. Five years of Arctic sea ice freeboard measurements from the ice, cloud and land elevation satellite. J. Geophys. Res. 114, C04008.

Forsberg, R., Skourup, H., 2005. Arctic Ocean gravity, geoid and sea-ice freeboard heights from ICESat and GRACE. Geophys. Res. Lett. 32, L21502.

Gagnon, A.S., Gough, W.A., 2005. Trends in the dates of ice freeze-up and breakup over Hudson Bay, Canada. Arctic 58 (4), 370-382.

Gagnon, A.S., Gough, W.A., 2006. East-west asymmetry in long-term trends of landfast ice thickness in the Hudson Bay region, Canada. Clim. Res. 32, 177-186.

Geiger, C., Müller, H.R., Samluk, J.P., Bernstein, E.R., Richter-Menge, J., 2015. Impact of spatial aliasing on sea-ice thickness measurements. Ann. Glaciol. 56 (69), 353-362.

Giles, K.A., Laxon, S.W., Wingham, D.J., Wallis, D.W., Krabill, W.B., Leuschen, C.J., McAdoo, D., Manizade, S.S., Raney, R.K., 2007. Combined airborne laser and radar altimeter measurements over the Fram Strait in May 2002. Remote Sens. Environ. 111 (2), 182-194.

Gough, W.A., Gagnon, A.S., Lau, H.P., 2004. Interannual variability of Hudson Bay ice thickness. Polar Geogr. 28 (3), 222-238.

Granskog, M.A., Kuzyk, Z.Z.A., Azetsu-Scott, K., Macdonald, R.W., 2011. Distributions of runoff, sea-ice melt and brine using $\delta 18 \mathrm{O}$ and salinity data-a new view on freshwater cycling in Hudson Bay. J. Mar. Syst. 88 (3), 362-374.

Hochheim, K.P., Barber, D.G., 2010. Atmospheric forcing of sea ice in Hudson Bay during 
the fall period, 1980-2005. J. Geophys. Res. 115, C05009.

Hochheim, K.P., Barber, D.G., 2014. An update on the ice climatology of the Hudson Bay System. Arct. Antarct. Alp. Res. 46 (1), 66-83.

Hochheim, H.P., Lukovich, J.V., Barber, D.G., 2011. Atmospheric forcing of sea ice in Hudson Bay during the spring period, 1980-2005. J. Mar. Syst. 88, 476-487.

Joly, S., Senneville, S., Caya, D., Saucier, F.J., 2011. Sensitivity of Hudson Bay sea ice and ocean climate to atmospheric temperature forcing. Clim. Dyn. 36 (9-10), 1835-1849.

Kaleschke, L., Tian-Kunze, X., Maas, N., Makynen, M., Drusch, M., 2012. Sea ice thickness retrieval from SMOS brightness temperatures during the Arctic freeze-up period. Geophys. Res. Lett. 39, L05501.

Kovacs, A., 1996. Sea ice: Part II. Estimating the full-scale tensile, flexural, and compressive strength of first-year ice. (96-11) CRREL Monogr (Hanover, NH).

Kurtz, N.T., Galin, N., Studinger, M., 2014. An improved CryoSat-2 sea ice freeboard retrieval algorithm through the use of waveform fitting. Cryosphere 8, 1217-1237.

Kwok, R., 2001. Deformation of the Arctic ocean sea ice cover between November 1996 and April 1997: a qualitative survey. In: IUTAM Symposium on Scaling Laws in Ice Mechanics and Ice Dynamics. Springer, Netherlands, pp. 315-322.

Kwok, R., 2005. Variability of Nares Strait ice flux. Geophys. Res. Lett. 32, L234502.

Kwok, R., 2014. Simulated effects of a snow layer on retrieval of CryoSat-2 sea ice freeboard. Geophys. Res. Lett. 41, 5014-5020.

Kwok, R., Cunningham, G.F., 2008. ICESat over Arctic sea ice: estimation of snow depth and ice thickness. J. Geophys. Res. 113, C08010.

Kwok, R., Cunningham, G.F., 2015. Variability of Arctic sea ice thickness and volume from Cryosat-2. Phil. Trans. R. Soc. A 373 (20140157).

Kwok, R., Rothrock, D.A., 2009. Decline in Arctic sea ice thickness from submarine and ICESat records: 1958-2008. Geophys. Res. Lett. 36, L15501.

Kwok, R., Cunningham, G.F., Zwally, H.J., Yi, D., 2006. ICESat over Arctic sea ice: interpretation of altimetric and reflectivity profiles. J. Geophys. Res. 111, C06006.

Kwok, R., Cunningham, G.F., Zwally, H.J., Yi, D., 2007. Ice, cloud, and land elevation satellite (ICESat) over Arctic sea ice: retrieval of freeboard. J. Geophys. Res. 112, C12013.

Kwok, R., Cunningham, G.F., Wensnahan, M., Rigor, I., Zwally, H.J., Yi, D., 2009. Thinning and volume loss of the Arctic Ocean sea ice cover: 2003-2008. J. Geophys. Res. 114, C07005.

Lammers, R.B., Shiklomanov, A.I., Vörösmarty, C.J., Fekete, B.M., Peterson, B.J., 2001 Assessment of contemporary Arctic river runoff based on observational discharge records. J. Geophys. Res. Atmos. 106 (D4), 3321-3334.

Landy, J., Ehn, J., Shields, M., Barber, D., 2014. Surface and melt pond evolution on landfast first-year sea ice in the Canadian Arctic archipelago. J. Geophys. Res. 119, 3054-3075.

Laxon, S.W., Giles, K.A., Ridout, A.L., Wingham, D.J., Willat, R., Cullen, R., Kwok, R., Schweiger, A., Zhang, J., Haas, C., et al., 2013. CryoSat-2 estimates of Arctic sea ice thickness and volume. Geophys. Res. Lett. 40, 732-737.

Markus, T., Cavalieri, D.J., 1998. Snow depth distribution over sea ice in the Southern Ocean from satellite passive microwave data. In: O'Jefferies, M. (Ed.), Antarctic Research Series, Antarctic Sea Ice: Physical Processes, Interactions and Variability. American Geophysical Union, Washington D.C., pp. 19-39.

Markus, T., Stroeve, J.C., Miller, J., 2009. Recent changes in Arctic sea ice melt onset, freezeup, and melt season length. J. Geophys. Res. 114, C12024.

Maslanik, J., Stroeve, J., 2016. DMSP SSM/I-SSMIS Daily Polar Gridded Brightness Temperatures, Version 4. (Boulder, Colorado, USA).

Maslanik, J.A., Fowler, C., Stroeve, J., Drobot, S., Zwally, J., Yi, D., Emery, W., 2007. A younger, thinner Arctic ice cover: increased potential for rapid, extensive sea-ice loss. Geophys. Res. Lett. 34, L24501.

Melling, H., Gratton, Y., Ingram, G., 2001. Ocean circulation within the north water polynya of Baffin Bay. Atmosphere-Ocean 39, 301-325.

Morison, J., Kwok, R., Peralta-Ferriz, C., Alkire, M., Rigor, I., Andersen, R., Steele, M., 2012. Changing Arctic Ocean freshwater pathways. Nature 481, 66-70.

Myers, R.A., Akenhead, S.A., Drinkwater, K., 1990. The influence of Hudson Bay runoff and ice-melt on the salinity of the inner Newfoundland shelf. Atmosphere-Ocean 28, 241-256.

Parkinson, C.L., Cavalieri, D.J., 2008. Arctic sea ice variability and trends, 1979-2006. J.
Geophys. Res. 113, C07003.

PEW Charitable Trust, 2016. The Integrated Arctic Corridors Framework. (April).

Prinsenberg, S.J., 1988. Ice-cover and ice-ridge contributions to the freshwater contents of Hudson Bay and Foxe Basin. Arctic 41 (1), 6-11.

Prinsenberg, S., Peterson, I., 2003, January. Comparing ice chart parameters against ice observations. In: Proceedings of The Thirteenth International Offshore and Polar Engineering Conference. International Society of Offshore and Polar Engineerspp. 25-30 May Hawaii, USA.

Regehr, E.V., Lunn, N.J., Amstrup, S.C., Stirling, I., 2007. Effects of earlier sea ice breakup on survival and population size of polar bears in western Hudson Bay. J. Wildl. Manag. 71 (8), 2673-2683.

Ricker, R., Hendricks, S., Helm, V., Skourup, H., Davidson, M., 2014. Sensitivity of CryoSat-2 Arctic sea-ice freeboard and thickness on radar-waveform interpretation. Cryosphere 8, 1607-1622.

Ryvlin, A.I., 1974. Method of forecasting flexural strength of an ice cover. Probl. Arct. Antarct. 45, 79-86.

Saucier, F.J., Senneville, S., Prinsenberg, S., Roy, F., Smith, G., Gachon, P., Caya, D., Laprise, R., 2004. Modelling the sea ice-ocean seasonal cycle in Hudson Bay, Foxe Basin and Hudson Strait, Canada. Clim. Dyn. 23, 202-326.

Schweiger, A., Lindsay, R., Zhang, J., Steele, M., Stern, H., Kwok, R., 2011. Uncertainty in modeled Arctic sea ice volume. J. Geophys. Res. 116, C00D06.

Stern, H.L., Heide-Jørgensen, M.P., 2003. Trends and variability of sea ice in Baffin Bay and Davis Strait, 1953-2001. Polar Res. 22 (1), 11-18.

Stewart, D.B., Barber, D.G., 2010. The ocean-sea ice-atmosphere system of the Hudson Bay Complex. In: Ferguson, S.H., Loseto, L.L., Mallory, M.L. (Eds.), A Little Less Arctic: Top Predators in the World's Largest Northern Inland Sea, Hudson Bay. Springer, New York, pp. 1-36.

Stewart, E.J., Tivy, A., Howell, S.E.L., Dawson, J., Draper, D., 2010. Cruise tourism and sea ice in Canada's Hudson Bay region. Arctic 63 (1), 57-66.

St-Laurent, P., Straneo, F., Dumais, J.F., Barber, D.G., 2011. What is the fate of the river waters of Hudson Bay? J. Mar. Syst. 88 (3), 352-361.

Stroeve, J.C., Markus, T., Boisvert, L., Miller, J., Barrett, A., 2014. Changes in Arctic melt season and implications for sea ice loss. Geophys. Res. Lett. 41, 1216-1225.

Tang, C.C.L., Ross, C.K., Yao, T., Petrie, B., DeTracey, B.M., Dunlap, E., 2004. The circulation, water masses and sea-ice of Baffin Bay. Prog. Oceangr. 63, 183-228.

Tian-Kunze, X., Kaleschke, L., Maass, N., 2013. SMOS Daily Sea Ice Thickness [Nov 2010-Jan 2016]. Digital Media, ICDC, University of Hamburg, Hamburg, Germany (updated 2016).

Tian-Kunze, X., Kaleschke, L., Maaß, N., Mäkynen, M., Serra, N., Drusch, M., Krumpen, T., 2014. SMOS-derived thin sea ice thickness: algorithm baseline, product specifications and initial verification. Cryosphere 8, 997-1018.

Tilling, R.L., Ridout, A., Shepherd, A., Wingham, D.J., 2015. Increased Arctic sea ice volume after anomalously low melting in 2013. Nat. Geosci. 8, 643-646.

Tschudi, M., Fowler, C., Maslanik, J., Stewart, J.S., Meier, W., 2016. Polar Pathfinder Daily $25 \mathrm{~km}$ Ease-grid Sea Ice Motion Vectors. Version 3. (Boulder, Colorado USA).

Ulaby, F.T., Moore, R.K., Fung, A.K., 1982. Microwave Remote Sensing: Active and Passive. Artech House, Boston, MA.

Valeur, H.H., Hansen, C., Hansen, K.Q., Rasmussen, L., Thingvad, N., 1996. Weather, Sea and Ice Conditions in Eastern Baffin Bay, Offshore Northwest Greenland, a Review. Danish Meteorological Institute (Technical Report 96-12).

Wang, J., Mysak, L.A., Ingram, R.G., 1994. Interannual variability of sea-ice cover in Hudson Bay, Baffin Bay and the Labrador Sea. Atmosphere-Ocean 32, 421-447.

Warren, S.G., Rigor, I.G., Untersteiner, N., Radionov, V.F., Bryazgin, N.N., Alexandrov, Y.I., 1999. Snow depth on Arctic Sea ice. J. Clim. 12, 1814-1828.

Wingham, D.J., Francis, C.R., Baker, S., Bouzinac, C., Brockley, D., Cullen, R., de ChateauThierry, P., Laxon, S.W., Mallow, U., Mavrocordatos, C., Phalippou, L., 2006. CryoSat: a mission to determine the fluctuations in Earth's land and marine ice fields. Adv. Space Res. 37 (4), 841-871.

Zwally, H.J., Schutz, R., Bentley, C., Bufton, J., Herring, T., Minster, J., Spinhirne, J. Ross, T., 2014. GLAS/ICESat L2 Sea Ice Altimetry Data, Version 34. (Boulder, Colorado. Retrieved June 2015). 